\title{
Politics and Audit in Malaysia
}

\author{
Azham Md. Ali \\ Faculty of Accountancy, Universiti Utara Malaysia \\ Sintok 06010, Jitra, Kedah Darul Aman, Malaysia \\ Email: azham@uum.edu.my
}

Accepted: October 08, 2014

Doi:10.5296/ jpag.v4i4.6626 URL: http://dx.doi.org/10.5296/ jpag.v4i4.6626

\begin{abstract}
This work investigates the role and contribution of external auditing as practised in Malaysian society during the forty year period from independence in 1957 to just before the onset of Asian Financial Crisis in 1997. It applies the political economic theory introduced by Tinker (1980) and refined by Cooper \& Sherer (1984), which emphasises the social relations aspects of professional activity rather than economic forces alone. In a case study format where qualitative data were gathered mainly from primary and secondary source materials, the study has found that the function of auditing in Malaysian society in most cases is devoid of any essence of mission; instead it is created, shaped and changed by the pressures which give rise to its development over time. The largely insignificant role that it serves is intertwined with the contexts in which it operates.
\end{abstract}

Keywords: External audit, Malaysia, politics, history, economy 
The activity of external auditing conducted by audit firms intervenes between the preparation of financial and non-financial information relating to a particular entity by management and the (supposed) use by many different groups of users of this audited information. In Malaysia, this audit is characterised by little publicity and little public clamour for needed changes. There may be a few lone voices from both the public and private sectors asking the auditors and their representative bodies the Malaysian Institute of Accountants (MIA) and the Malaysian Associations of Certified Public Accountants (MACPA) to do a better job, but that seem to be where the "story" ends. ${ }^{\text {i }}$ From time to time there would also be certain expose' which provide the picture that external audit in the country is in need of a certain level of revamp.

Examples include the revelation made by the Central Bank of Malaysia that the main issues of contention between the Central Bank and the external auditor were a consequence of the auditor having compromised his or her independence proven in two areas of financial reporting: disclosure and the provision figure for bad and doubtful accounts (Central Bank, 1987, p. 6). On the former issue in particular, there had been cases where the auditor either worked together with management or agreed with management efforts at "window-dressing" the accounts leading towards inadequate disclosure of significant changes in accounting policy and/or unneeded adjustments to certain items disclosed. A few years later in 1991, it was an auditor himself, Mr. Khoo Eng Choo, the senior partner of the Price Waterhouse, who mentioned that there were local auditors who "... have been found not to have exercised sound professional judgement" (Choo, 1991, p. 23). He also made the following revelation (p. 23): "It is also unfortunate that sometimes some members of the profession have sunk to the level of enabling some unscrupulous members of the business community to dictate to them the approach 'Just your signature' is enough. They become poodles or lapdogs of these businessmen. These members are tarnishing the image of the profession and have failed in their duties."

But even with these revelations, the one single case where a Malaysian auditor was brought to court took place in the mid-1960s when a group of company shareholders unhappy with the loss they incurred sued the auditor. ${ }^{\text {ii }}$ Thus, during economic recessions in the $1980 \mathrm{~s}$, when many businesses were forced to close down and cases of financial improprieties by directors and top management were disclosed, Malaysian auditors avoided being taken to court. In this regard, the then finance minister Datuk Paduka (now Tun) Daim Zainuddin was quoted by the New Straits Times ${ }^{i i i}$ (12 Sept. 1987) as saying that "... it is a miracle that no member of the public or any interested party has sued auditors for being professionally negligent taking into account the various "swindle" cases recently ...." The blissful existence of Malaysian auditors is certainly in contrast to that experienced by teachers/lecturers, government servants, politicians, Malay rulers, nurses who have all by the early 1990s entered the limelight of adverse publicity. Other professionals, such as physicians and lawyers have also in recent years been confronted with adverse public scrutiny. ${ }^{1}$

Indeed, if there is any profession or group of people in the country which seems to be able to operate with little challenge to its practices, it is the so-called company auditors. This in fact had led Oh Chong Peng, the then vice-president of the MACPA and also a senior partner of Malaysia's Coopers and Lybrand, to argue that there was still not much pressure coming from the Malaysian society for the auditor to extend his or her responsibilities - despite the recent numerous cases of failures of companies, both listed and unlisted, where the auditors failed to give warning by qualifying in their audit reports that these companies were not going-concerns (Peng, 1989). Thus, he pointed out, there was little need for the accounting profession to put forward reactive measures. Similar sentiment may also be found in the remarks made by his colleague the then MACPA president, Subimal Sen Gupta (The Malaysian Accountant, July 1987, p. 4). The latter figure had also pointed out that even the regulatory authorities were oblivious to the goings-on in audit. ${ }^{\mathrm{v}}$

What is happening in Malaysia is considerably different from that experienced by auditors in 
countries such as the United States, Britain, Canada and Australia. In these countries, they are often criticised for the business failures and a number have had to pay large damages or settle out of court with plaintiffs accusing them of committing audit failures. Besides the court, regulatory agencies and other groups have also played their part in demanding that the profession move in an expeditious fashion to meet its responsibilities as perceived by the public (see Flint, 1983; Bruce, 1988; Humphrey et al., 1992; and Jacob, 1992). In these countries even when external economic factors force businesses into liquidation and there is little proof of auditors' failure to conduct audit properly, the auditors nonetheless become implicated in the failure.

Even when Malaysia's auditing experience is compared to others such as South Korea, Hong Kong, India and Singapore in Asia, the situation in Malaysia is a source of surprise. This is because unlike what happens in Malaysia, their auditors had experienced tough time from the authorities. ${ }^{\text {vi }}$ In the case of South Korea and Singapore, the auditors concerned have also been brought to court by the affected investors. ${ }^{\text {vii }}$

This paper thus attempts to explain this Malaysian audit phenomenon by applying the alternative contextual view of accounting i.e. the theory of political economy. With the theory of political economy introduced by Tinker (1980) and refined for accounting by Coopers and Sherer (1984), attempts are made to understand how the distribution of power in society and the social, political and institutional structure that mirrors that distribution of power have impacted the functioning of audit in Malaysia across a period of forty years, from the gaining of independence from the British in August 1957 to the time just before the emergence of Asian Financial Crisis in the third quarter of 1997. In other words, auditing is understood here to be interrelated with the dynamics of the wider sociopolitical and economic context of which it is an integral part. It is considered to be a mutable phenomenon, interacting with a dynamic, mutable context (Hopwood, 1987). By examining the social, economic and political environments surrounding auditing together with developments within auditing itself, it is hoped that the original, present and potential functions of auditing in Malaysia will be disclosed fairly - perhaps in the spirit of the following remark by Burchell et al. (1980, p.13): "... accounting, it would appear, is made to be purposive rather than being inherently purposeful."

While this is a country-specific study, it provides a contribution within the framework of international comparative auditing research (professionalisation or professional development's) by adding to studies of the causes and effects of auditing variation between countries classified under the typology of fast developing economies. Another form of contribution of this work is concerned with the issue raised by Willmott (1991, p. 109): that the study of auditing "has been seriously neglected and marginalised, even as evidence of 'failures' mounts and doubts about the independence of auditors grow". It is thus hoped that this paper will be able to contribute in some way towards enriching this very important area. Finally, by doing this work, it is specifically hoped that the profile of auditing is raised in Malaysia to direct the attention of more influential parties (e.g. politicians, civil servants, journalists, consumer groups) to ask probing questions about the operation and adequacy of the existing audit regulatory arrangements (Sikka et al., 1989; Willmott, 1985) with the focus also on other systems neighbouring to the audit practice.

The paper begins with a discussion of the theory of political economy of accounting. It is followed by a section on data collection. A section describing the goings-on in the audit arena and surrounding area comes right after. This section is divided into three parts: the early beginning, the NEP era and the post-NEP era of 1987-1997. In trying to make sense of what had taken place, the subsequent section applies the theory of political economy of accounting where the discussion is imparted in two parts: pre-NEP era and NEP plus era. The paper ends with a section on conclusions. 


\section{The Political Economy of Accounting}

2014, Vol. 4, No. 4

The political economic theory was introduced by Tinker (1980) and refined by Cooper and Sherer (1984) to explain accounting experiences. Tinker (1980) in introducing a classical political economic approach to financial reporting proposes that the social relations of production work together with the economic forces of production as two related dimensions of capital shaping the social and economic life of a nation. He points out that in any society the coming together of the two modes of production is discernible in the particular socio-political and economic institutional forms and arrangements. The use of political economic theory that recognises the presence of social relations makes it less cumbersome to understand the economic forces of production that are operating at any particular time period and in any society. Tinker explains that such relations are reflected through a set of institutional forms and arrangements that are constructed to interact with economic relations (i.e. the type of economy).

Therefore, in order to understand what is going on in the economic sphere, which may include the external audit function, researchers need to identify the related socio-economic and institutional environment. Interpretation of a nation's specific economic features will be less adequate if insufficient attention is given to the surrounding social and political processes. In regard to accounting activity in particular, Cooper and Sherer (1984) point out that a political economy of accounting is useful for understanding how the accounting process interacts with its social, economic and political environment. They write (p.208):

... the objectives of and for accounting are fundamentally contested, arises out of recognition that any accounting contains a representation of a specific social and political context. Not only is accounting policy essentially political in that it derives from the political struggle in society as a whole but also the outcomes of accounting policy are essentially political in that they operate for the benefit of some groups in society and to the detriment of others.

Thus, it is assumed that there exists no basic harmony of interests in current society. Auditing practice is viewed as favouring specific dominant interests in society and disadvantaging others. That is, what transpires in the audit process would be in accord with the expectations or goals of these dominant parties. Cooper and Sherer (1984) have also identified the presence of several key variables which they claim affect the value of financial accounting reports including power-play in society and historical specificity. On the former, they argue that social-relations of power and conflict ${ }^{\text {viii }}$ determine accounting's significance, which in turn affects such relationships. Instead of assuming a basic harmony of interests in society where power is widely diffused and which results with the unproblematic view of the social value of accounting reports, the political economy approach supports the following contrasting views: either that society is seen clearly controlled by a well defined elite or that there is a continuing conflict in society between antagonistic classes. ${ }^{\text {ix }}$ Both views of elitist domination and pluralist anarchy signify the contested value of the accounting reports and practices. Thus, accounting reports are hardly impartial and objective, nor is the accountant in the position of a disinterested and innocuous historian.

The latter variable of historical specificity stresses the importance of the specific historical and institutional environment comprising the social and political structures and cultural values of the society that provide the context for the delivering of the accounting reports. There is recognition that "disequilibrium is a standard feature of the economy" as proven by the presence of a few large corporations dominating the economy and that the state plays paramount roles in various fields including that of intervening in the determination of accounting policies. The historical focus in particular should assist efforts to understand the changing roles of accounting practice and emphasises the importance of historical specificity for a fair assessment of the social value of these roles.

In summary, a political economy of accounting focuses on the institutional environment which supports the existing system of corporate reporting. It looks at the accounting function within the broader structural and institutional environment in which it operates. It stresses that political issues cannot be divorced from economic analysis in relation to social 
choices. It revolves around power and whose interests predominate in society which inevitably impact upon auditing. Thus, under the political economy approach, the focus on social relations leads to the proposition that certain parties possess special interests that often influence the audit process.

Also, with political economy as the theoretical framework, the rationale for Malaysia's audit functioning may be discovered by linking the history of the nation's audit practice with the nation's history in the social, economic and political spheres. Thus, the understanding is viewed as coming about not through the study of separate and overt elements of the audit infrastructure and its technical outputs but through a more comprehensive and in-depth study of these and other items considered crucial to such an understanding. The assumption held throughout is that the audit activities taking place within a certain length of time is associated with a unique configuration of social, economic and political conditions. That is, these activities are products of the social, economic and political realities and differences in audit activities across several time periods may be traced to the changes in these realities. It is very much recognised however that the "story" told is most probable only one of many. As succinctly noted by Carnegie and Napier (1996, p. 30): "Researchers starting from quite distinct theoretical perspectives and with disparate moral and political attitudes could well narrate virtually the same chronology of "facts": how those facts are interpreted is likely to differ widely."

\section{Data Collection}

The study relies upon qualitative data gathered by utilising the technique of documentary analysis. All the documents referred to lend insight into the perspectives, assumptions, concerns and activities of those who produced them. The primary written materials accessed and analysed were comprised mainly the annual reports of the accounting bodies of the MIA and the MACPA and government documents such as the numerous Malaysian Plans. The secondary written sources relied on to provide data on Malaysia's auditing are few and far between. There were conference materials at the ASEAN level where materials on Malaysia's auditing are discussed and a few others at national level and books by Gul (1983) and Enthoven $(1973,1977)$. When it concerns the nation's social, economic and political environments, numerous secondary written sources were accessed including various authoritative sources published over the years in and outside of the country. The same was done in investigating development in the nation's history and in systems of relevance to audit: corporations, government and capital funds.

Much of these materials were collected during the field work which took place in the first six months of 1997. However, the rest, especially in the area of accounting/auditing in Malaysia, was collected long before the field work began and which had culminated with the publication of a book published locally (see Azham, 1994).

Finally, it needs to be noted that this study is part of a bigger one on accounting development in Malaysia where among others in-depth interviews with selected personalities were conducted. A number of these personalities were leaders of Malaysia's accounting profession. Where appropriate, materials from these interviews are also introduced in this paper to add up to the points raised. These cases are however very few and far between. Details regarding the interviews may be found in Azham (2002).

\section{Audit in Malaysia over the Years}

It appears that certain territories of what presently constitute parts of Malaysia have had some form of external auditing practised long before the nation's independence in 1957. This could be explained with the presence of British investments in these territories, then known as Straits Settlements, starting from the beginning of the 19th century (Allen and Donnithorne, 1954). By late nineteenth century, much of the international trade conducted through the Straits Settlements was dominated by a few merchant houses (Jomo, 1986, p. 145). By the time of independence, the corporate sector was dominated by rubber estates and tin mines whose owners were European, predominantly British. These publicly owned companies were 
managed by the merchant houses (Kennedy, 1993, p.206; Junid, 1980, Chapter Five). In such a context where ownership was separated from management, external auditing was a necessity for company reporting. Thus, it is not surprising to find that as early as 1910, the English Institute of Chartered Accountant had formed branches and/or affiliated societies in the Straits Settlements (Johnson and Caygill, 1971), that it was in 1909 that the audit firm of McAuliffe, Davis and Hope was established in Penang (Liang, 1989) and that the first Malaysian to qualify as a chartered accountant graduated in 1921 (Report on the First Forum of Accountants of ASEAN Member Countries, 1976, p. D16).

Came 1957, the Malay Federation gained its independence from Britain. And later in 1963, Malaysia was formed when the independent Malay Federation came together with the British colonies of Singapore, Sabah and Sarawak. Singapore however withdrew from Malaysia in August 1965 and became an independent republic. The audit arena in the early years was marked by three significant developments involving the setting up of the Malaysian Association of Certified Public Accountants (MACPA) and the Malaysian Institute of Accountants (MIA) and the passing of Companies Act 1965 with sections on accounts and audit. In later years, the MIA and the Companies Act saw years of inertia followed by active ones. As for the MACPA, it was very active all the while. During the forty years after the Malay Federation gained independence in 1957, as to be expected, the nation saw increased number of auditors and audit firms paralleling the nation's economic progress.

Thus, just a few years prior to Asian Financial Crisis in 1997-98 when the nation was about to arrive at the peak of its economic development, it was reported there were around 2000 auditors working in over 800 audit firms in the country with over 250,000 companies demanding auditing yearly (Akauntan Nasional, Apr. 1993, p. 25). The larger firms were known to provide a wide-range of services besides external auditing and all these services were bought by not only registered companies but also by others such as individuals, multi-national corporations, government departments and statutory bodies. For the larger audit firms, normally there existed links-up with audit firms from overseas. ${ }^{\mathrm{x}}$

In the following section, the early beginning of audit development and the trials and tribulations faced by a number of players in the audit arena in later years is described. It begins with audit developments taking place right after the independence of Malay Federation. It is followed by the goings-on in the audit arena during the years when the New Economic Policy (NEP) was taking place. This section ends with the description of what happened during a period of just over ten years prior to the onset of the Asian Financial Crisis in the third quarter of 1997. With the application of the theory of political economy of accounting, this section also describes developments taking place in the area surrounding the audit arena, such as the government and corporate sectors, and their impacts. To differentiate this discussion with the one following, more emphasis is however given on developments taking place within the audit arena.

\section{The Audit Beginning of a Newly Independent Nation}

When the Malay Federation gained its independence from Britain in 1957, it came about through peaceful means - the "interracial bargains" among the nation's political leaders from the Malay, Chinese and Indian communities and the peaceful negotiations between them and the British (Vreeland et al., 1976). In regard to the latter, Limlingan (1994, pp. 95-96) noted that the "promises" extracted by the British from the nation's leaders (as the prerequisite for the former's willingness to transfer power) included among others the continuance of an economic policy of free enterprise which meant the non-nationalisation of British-owned companies. Therefore, the nation's economy under the immediate post-colonial government had changed little from that under the British colonial administration. The foreigners, particularly the British merchant agency houses, were still in charge. As perhaps to be expected, the various activities taking place in the nation's audit arena then were mirrors of those overseas so that the interest of the British shareholders and other overseas owners of these businesses would continue to be protected.

The passing of the Companies Act 1965 and the Accountants Act 1967 pushed for the 
emergence of the initial pattern of audit system, replacing a pre-existing pattern where there was no law to govern the operations of companies throughout the newly formed federation ${ }^{\mathrm{xi}}$ and a national accounting body to represent all qualified accountants in the country. These Malaysian Acts are similar to those found overseas.

The Companies Act 1965 drew mainly on two sources: the Victoria Companies Act of 1961 and the British Companies Act 1948 (Walton, 1986). ${ }^{\text {xii }}$ The former in turn was based upon UK Companies Act 1908, 1929 and 1948 while the latter on UK Companies Act 1929. The Act demanded companies to disclose more than ever before. It also requires companies to keep accounting records so as to have true and fair statements prepared and that record keeping should be executed in such a way so to enable the records to be conveniently and properly audited.

In matters of auditing, the Act stressed the need for the auditor to be independent where he or she was not allowed to be an officer or director or had share holding (either direct or indirect) with the companies audited. In addition, the auditor was given a very broad power base in matters of inspecting records and obtaining information for audit and had the right to attend and address the general meetings of the company. As in the earlier Companies Ordinance 1946, the academic and professional qualifications of the auditor were not specified. However, under section 8 of the Companies Act, a person had to apply to the finance minister to gain license to become a company auditor. ${ }^{\text {xiii }}$ In order to get the license, he or she besides being Malaysian resident must be able to satisfy the finance minister of his or her good character and competency to perform the duties of an auditor. The passing of the Accountants Act 1967 roughly a year after the Companies Act came into existence had ensured however that being a member of the MIA is a requirement before one would be given the permission to audit although the Companies Act 1965 has not made that clear (Shing, 1981, p. 32; Abu-Hassan, 1986, p. 4).

The Accountants Act 1967 resembles the Singapore Society of Accountants Ordinance 1963 which in turn was based upon the New Zealand Society of Accountants Act - the main difference being that the Malaysian Act was "much briefer" and thus "less explicit" than the Singaporean Ordinance (Hai, 1970/71, pp. 27-28). With the Accountants Act 1967 coming into existence in September that year, the MIA emerged as the nation's accounting statutory body. Section 6 of the Act notes five functions of the MIA including the responsibility to regulate the practice and promote the interests of the profession and to determine the qualifications of persons for admission as members. In regard to the latter in particular, the MIA is required to maintain a register of accountants. These accountants come under one of three categories of membership: public, registered and licensed accountants. ${ }^{\text {xiv }}$

To ensure only qualified people whose principal place of residence is Malaysia could act as public and registered accountants, the MIA through the Accountants Act has made it illegal under Sections 22 and 23 for anybody to hold him/herself out as a public, registered or licensed accountant or adopt, use or exhibit these titles or others such as auditors, tax consultants and tax adviser. ${ }^{\mathrm{x}}$ Any transgression would mean the person is liable for a fine maximum RM 1000 or imprisonment for up to one year for the first offence and with subsequent transgression he or she is liable for a fine maximum RM 2000 or imprisonment of two years. In short, as stated in the House of Representatives' Parliamentary Debates (Vol. IV, No. 12, Col. 2409 dated 25 Aug. 1967), the Act is intended to make provision for the adequate control of the accounting profession as a whole, and this control is to be entrusted to the MIA to be established under the Act.

Finally, in regard to the accounting body MACPA as opposed to that of MIA, it was established through the initiative of the private sector. To be more exact, in less than one year after independence, on 26 July 1958, twenty local accountants who were formerly members of the Malayan branch of the Association of Chartered and Incorporated Accountants (ACIA) and the Malayan branch of the Association of Certified and Corporate Accountants (ACCA), both established in 1936, came together and incorporated the Malayan (later Malaysian) Association of Certified Public Accountants (MACPA) in Singapore under 
the Straits Settlement Companies Ordinance 1940 (CERPASS, Dec. 1967, p. 51). MACPA was set up as a company limited by guarantee with the objective of advancing the status and development of the accounting profession in Malaysia and to provide the opportunity to those aspiring to qualify as an accountant to be trained under local law and practice (The Malaysian Accountant, July-Sept. 1988, p. 16). The latter was particularly crucial to the foreign-controlled corporate sector then due to the fact that the country had gained independence and accordingly was no longer in the position to accept non-citizens, i.e. the British accountants, to be practising as auditors in the country.

The MACPA was modelled upon the Institute of Chartered Accountants of England and Wales (ICAEW) and is a good example of those accounting professional bodies described by Parker (1989) as following the British institutions of professional accountancy. The 1980 MACPA president, Dr. Nawawi Mat Awin, had confirmed that that was the case. Said he (The Malaysian Accountant, Jan. 1981, p. 45): "Besides examinations, the founders of MACPA drew extensively on the experience of the English Institute in establishing the foundations of the profession, particularly in professional education, standards and discipline." It is notable that the MACPA whose first three presidents were westerners ${ }^{\mathrm{xvi}}$ had in February 1961 instituted the examination and articleship system of training accountants and registered its first batch of students (The Malaysian Accountant, July-Sept 1988, p. 10). The first MACPA examination - "Intermediate" - was held in December 1963 and the other two - "Final Part I and II" - in December 1965. All took place with the assistance of the Overseas Accountancy Examination Advisory Board (OAEAB) established by the Chartered Accountants Joint Standing Committee of the Institutes of Chartered Accountants of Scotland, England and Wales and Ireland. This support by the OAEAB was extended until 1969 (Enthoven, 1977, p. 323, p. 16; see also Johnson and Caygill, 1971, p. 167). ${ }^{\text {xii }}$

All in all, the newly independent nation appeared set on ensuring that activities in the nation's audit arena would fulfill the need of foreign investors. The same appeared to be the case in a related area of taxation where the government in its attempts to attract industrial investment from overseas had brought to itself the accusation of providing foreigners with excessive tax exemptions (Lim, 1973, p. 261; Edwards, 1975, Section 5.2). Specifically, among the limited companies in the manufacturing sector in 1971, the effective rate of direct taxation on profits was 67.6 percent and 39.9 percent for local and foreign companies, respectively; as for all limited companies in 1971, the rates were 59.8 percent and 39.5 percent, respectively (Jomo, 1986, p. 222). All this apparently took place when the rates of reinvestment ${ }^{\text {xviii }}$ by foreign-owned companies was much less compared to local-owned companies (see Hirschman, 1971, pp. 26, 30, Table 6; Peng, 1979, p. 192, Table 4.4; and Lindenberg, 1973). Thus, Jomo (1986, p. 247) was on the mark when he said: "In the early years after independence, the post-colonial state continued to serve the interests of British capital in particular, and foreign capital in general."

With the occurrence of violence between Malays and Chinese in 1969, it was realised that for the long term good of the country, there was a need to have changes taken place in the nation's economy and other sectors of Malaysian life. Thus, the subsequent implementation of the New Economic Policy (NEP) in 1971 heralded a new era where now foreign interests had to play a secondary role to those inside the country - in particular that of the government which entered the corporate sector in full steam. This had resulted with a profound impact on the audit arena as mentioned next.

\section{Audit in the NEP Era}

For years, there were underlying tensions existing between the Malays and Chinese. In May 1969, the tensions boiled over with the Malays and the Chinese fought on the streets of Kuala Lumpur resulting in nearly two hundred people dead and hundreds more injured. ${ }^{\mathrm{xix}}$ The racial riots had jolted many parties to the realisation that more riots would take place in the future as long as the country remained the same socially, politically and economically. Thus, drastic moves had to be made in many fields. In the socio-economic field, the NEP was initiated in 1971 with the goals of eradicating poverty - regardless of race and irrespective of 
geographical location - and reducing imbalances in income, employment and ownership of assets among the various races in the country. In trying to meet these objectives by 1990 the government implemented a number of strategies.

Among the notable ones included the pursuance an ownership and employment restructuring program enforced on both non-indigenous domestic and foreign owned firms (Zainal-Aznam, 1991a; Jesudason, 1989; Woon and Kam, 1989; Onn, 1989; Means, 1986; Chan and Horii, 1986; Redha, 1985; Woon, 1982). Thus, laws such as the Petroleum Development (Amendment) Act and the Industrial Coordination Act were passed in 1975 which had the goal of greater government control over industries. The large and powerful merchant agency houses such as Guthrie and Sime Darby now had to employ more Malays to fill the quota, restructure their capital to meet the Malay equity requirements and enter into joint ventures with entities established by the government.

The government which emphasised direct participation in the nation's economy "on behalf" of the indigenous population (known as "Bumiputra") also established various trusts that used government funds to purchase foreign-owned shareholdings. As a result, the government or government-owned entities dominated a number of sectors, particularly plantations and financial institutions. In fact, in a period of seven years after the launching of the NEP in 1971, the state had taken ownership and control of almost all the large plantations: Sime Darby, Guthries, Boustead, Highland and Lowlands, Barlow and Harrisons and Crossfield (Hui, 1988, p. 24; see also Horii, 1991; Saruwatari, 1991). And in 1976, the government took control of the largest tin-production in the world.

By 1976 too the state had a share of at least 40 percent in each of the three largest domestic banks (Peng, 1983, p. 121): Bank Bumiputra, Malayan Banking and United Malayan Banking Corporation. And by 1980, the state owned 77.4 percent of the local banking industry and 50 percent of the total banking industry (Hui, 1988, p. 24). Thus, the government had basically direct control over much institutional credit and this in turn signified its influence not just over its enterprises but also over the rest of the business community. The part played by the government as the nation's banker was quite crucial, considering the fact that the stock market - which initially arose out of the tin and rubber industries of the 1930 - was nothing of consequence to any party during this time. It was more a place for gambling by the very rich - just like what it was before. ${ }^{\mathrm{xx}}$

While the government got intensely involved in the industrial sector and the import/export business partly through taking over British merchant, the rest of the business sector - the small and medium sizes of enterprises - which was in the hands of local Chinese had also begun to evolve from majority sole proprietorships and partnerships to corporations in the late 1970s (Wai, 1982). This appeared to represent an attempt by these Chinese to compete with the government companies (see Limlingan, 1986, p. 111; Hui, 1988, pp. 25-26; Hara, 1991). One of these Chinese companies the Multi-Purpose Holdings (MPH) was backed by Malaysian Chinese Association (MCA), the local Chinese main political party: over 96 percent of its equity as of September 1982 was held by individual MCA members (44.2 percent) and Koperasi Serbaguna Malaysia (KSM-Cooperative Society of Malaysia) (52 percent) which was formed in 1966 by the youth wing of the MCA. Besides issuing shares, the MPH also relied on banks' loans for its funding. Among the banks which provided the loan was the Overseas Chinese Banking Corporation (OCBC) - noted to be the most significant provider of Chinese capital for the top Malaysian corporations in 1974 (Hui, 1983). OCBC, the oldest local bank in Malaysia and Singapore, is owned and controlled primarily by a few Singaporean and Straits Chinese families. The business organisation of the MPH was emulated by other Chinese groups and state organisations of the MCA (Limlingan, 1986, p. 113).

With foreign interests no longer being of paramount importance in the nation's economy, the earlier "carrots" such as the Companies Act 1965 (which requires companies to undergo audit annually) and the Accountants' Act 1967 (which leads to the forming of the MIA as national accounting body in 1967) were left unapplied until the second half of 1980s - when changes 
to a good extent were made to the NEP. Thus, the promising beginning in the audit arena in the 1960s had gone nowhere by the end of the decade. Perhaps this was inevitable in a context where the strong presence of the government and the increasing involvement of local Chinese in the corporate sector signified that these corporations were owned, managed and funded by people from their own respective Malay and Chinese communities who shared goals that were not only economic but also social and political. The enterprises were registered as companies but in actuality they were unlike those known as companies in the western sense of the word "company" with conflicting interests of different parties. There was thus little need for "independent" auditor and accordingly a strong, capable representative professional cum regulatory body to be around.

The MIA in Doldrums. Following the appointment of the then Accountant-General ${ }^{\mathrm{xxi}}$ as the MIA's president on 31 May 1968, not even a single AGM was conducted in the next two decades. The MIA under his leadership which finally came to an end in April 1987 presumably took over the role of "registering body". xxii But even this was delegated to the audit firm Price Waterhouse. In 1982, the MACPA took over this responsibility. (See a set of untitled bounded documents in the MIA library, stamped on its first page as "Confidential" and dated 1 October 1988 and which appears to have been forwarded to the then finance minister by the MIA council to gain his approval for the various amendments suggested for the Accountants Act 1967. From hereon it will be referred to as the "MIA 1988 Bounded Document".)

The registering role of the MIA in those two decades was well articulated by the MIA president, Haji Hanifah Noordin, just before the first MIA annual general meeting in 1987. He said that "... the earlier members of the [MIA] council not be entirely blamed for the inactive state of the MIA because in the earlier years it was felt that it should only be involved in its limited role of registering accountants in the country" (Business Times, 10 Sept. 1987). Unfortunately, the MIA did not execute that chosen function successfully. In other words, there were those fully qualified to register with the MIA who had failed to do so. Thus, just a few months after MIA was activated in 1987, it was found that as of 29 February, 1988, of the country's 6000 or so qualified accountants only 4453 had registered themselves with the MIA (NST, 20 March 1988). The reminder who did not register were comprised of 600 members of the MACPA, 800 of the Chartered Association of Certified Accountants (CACA) and 200 accounting graduates from local universities.

It may safely be said that nothing substantial had actually taken place in the 1970s except for the passing of Accountants' Rules in 1972 which, however, were not enforced due to the nonexistence of the statutory investigative and disciplinary committees which could only be formed by the MIA after an AGM. Thus, as reported by The Malay Mail (13 Jan. 1988), just a few months after the MIA was activated in 1987: "The recently activated institute has formed investigation and disciplinary committees in September to regulate the profession after 20 years of existence." And the MIA president himself mentioned in a seminar paper (Hanafiah, 1990, p. 17): "There was no enforcement of the Accountants Act 1967 in its twenty years of dormancy."

Note however that while acting as a body to register accountants, during its inactive years, the MIA leaders had conducted a series of discussion with those from the MACPA to have the two bodies "merged". The MIA 1967-87 Annual Report (p. 14) pointed out that the MIA and the MACPA began their merger discussions on 7 December, 1972. ${ }^{\text {xiii }}$ In February the following year, the MIA formed a liaison committee ".... to study and pave the way for establishing dialogue with the MACPA with the objective of uniting the accountancy profession in Malaysia" (MIA 1967-87 Annual Report, p. 14). In 1979, Megat Abdul Rahman, the then vice-president of the MACPA, presented in a seminar what the merged body Malaysian Institute of Chartered Accountants (MICA) would look like (Megat, 1979, pp. 14-20). Details of the proposal developed by a committee of the MACPA provided the picture that the MACPA had the upperhand in deciding the nation's audit future (see Azham, 2002). This perhaps was not surprising for the government then appeared to have not stopped the MACPA to be active and self-regulating to cater for the foreign economic 
interests that were still operating heavily in the country then, particularly in the manufacturing sector. Unfortunately, the MACPA had conducted many of its affairs on financial reporting and accounting professionalisation in a manner that alienated others, planting seeds for much uneasiness later in the late 1980s and 1990s with a revived MIA (see Azham, 2002).

In the meantime, with a very discouraging picture for auditing helmed by a body behaving as if it was representing majority if not all of the company auditors then, various debilitating outcomes took place in the nation's audit arena within the next ten years, the decade of 1970s, and continued well into the following decade. Two notable ones were disciplinary chaos and proliferation of unqualified accountants/auditors.

Disciplinary Chaos. The investigation and disciplinary committees of the MIA were not formed until September 1987 after its first AGM. Therefore, in the area of professional ethics and their enforcement the Malaysian accounting profession, up to the late 1980s when the MIA was activated, appeared to be in a state of chaos. This could perhaps be seen from the remark made by the then MACPA president, Subimal Sen Gupta, in 1986 where he mentioned that the MACPA as a "private body" could only be strict with its members who did not comply with the body's ethical code and that the body had no control over those who were not its members but who deserved to be disciplined. Next he said (The Malaysian Accountant, Oct. 1986, p. 4): xxiv $^{\text {(1) }}$

The MACPA has no control over the issue of the audit license to individuals which qualifies them to act as Approved Company Auditors. This license is issued by the Ministry of Finance by reference to the Malaysian Institute of Accountants (MIA). I therefore appeal to both these bodies to take cognisance of the disciplinary actions taken by MACPA against its members by taking appropriate action against them if they are also members of the MIA and holders of the audit license. More importantly perhaps there should be a mechanism for taking action against those who are not members of MACPA. The MACPA will be pleased to assist in this respect.

Note also what was revealed in the letter published in 1988 in the NST. In the letter written by a person who signed him/herself as "Disgusted", he described the mess in the then audit practice (NST, 6 Aug. 1988): "In the past any attempt [by MACPA] at disciplinary control over errant members resulted in those members discontinuing their membership with the MACPA and continuing to practice as public accountants as they are allowed to do under the Accountants Act 1967."

Proliferation of Unqualified Accountants/Auditors. The 1967 Accountants Act states that only those with recognised qualifications may practice or call themselves accountants/auditors. But with the MIA not fulfilling its policing role, unqualified accountants holding either unrecognised qualifications, part qualifications or no qualification had the opportunity to appear and grow with the then expanding economy in the 1970s and early 1980s. As stated in the MIA 1988 Annual Report (p. 13): "The problem of unqualified accountants, both in practice and in commerce and industry, had proliferated to serious proportions during the period of inactivity of the Institute." In early 1988, the MIA president disclosed that a study completed in 1981 (by what appeared to be the MACPA) found that there were 200 to 300 people who were not qualified accountants who were active as public accountants, auditors and tax advisers in the country (Berita Harian, 13 Jan. 1988). The number of unqualified accountants was changed later on in late 1988 to 3,000 with those they employed totalling to 15,000 (NST, 5 Nov. 1988). Most of the unqualified public accountants were also now identified to have come from corporate secretarial and administrative firms (The Star, 5 Nov. 1988).

Also in 1988, the MIA had pointed out that the unqualified accountants acting as auditors would collaborate with the qualified auditors in the sense that the latter would be paid a token fee (normally a 30 percent cut) for certifying and endorsing financial statements that had 
presumably been audited earlier by the unqualified auditors (NST, 20 March 1988). In the MIA 1988 Annual Report, the following was stated (p. 14): "The unqualified accountants would not have been able to function if not for some of our errant members who are prepared to sign the accounts prepared by them without any question at all." In 1993, the MIA estimated that there were between 50 and 100 licensed accounting firms collaborating with unqualified accountants (NST, 28 Jan. 1993).

It is notable that the 1981, 1982 and 1984 Annual Reports of MACPA mentioned the various efforts conducted by the MACPA in confronting the issue of unregistered accountants. The MACPA 1984 Annual Report for example mentioned that the MACPA had sent a memorandum to the Accountant-General who was the MIA president. Next it stated (p. 22): "We now await his action against persons identified in our memorandum as violating the provisions of the Accountants Act 1967." Apparently, he did not do anything that could make a difference. This should not perhaps be surprising for the fact that these accountants were needed in the then fast growing economy which was facing severe shortage of qualified accountants (see Committee on International Accounting Operation and Education, 1976-78, of the American Accounting Association, 1978, p. 39; Ahmad-Noordin, 1981, p. 25).

Overall, audit in Malaysia during the NEP era was in an uncertain and unsatisfactory state. While the MIA remained largely uninfluential, the privately organised MACPA with its power limited to only a fraction of the accountants population in the country and controlled by the internationally affiliated audit firms whose clients would include foreign investors, was left free by the government to do what it felt was right with hardly any interference or much expectation from the government. This led to the picture that financial reporting and the related matter of external auditing was largely superfluous in a society when the government as the main engine of the economy was not just the regulator but also the so-called user and preparer of audited statements - except in cases where there was a need for funds from foreigners to invest in the manufacturing sector who thus for one reason or another demand the presence of company audit and thus the external auditor.

Perhaps nothing else could describe the appalling state of audit during this period than the case of Bank Rakyat which was detailed out in a 1979 Parliamentary White Paper. In summary, Bank Rakyat was established in 1950. By 1975, it expanded its paid up capita to over RM 15 million and membership comprised of over twenty three thousands individuals and just over 1000 cooperative societies. It faced acute financial problems from 1973 which resulted in it being rescued by the government in 1977. The parliamentary paper revealed widespread corrupt activities by parties inside the bank and those related to it, including the external auditor, the audit firm Kassim Chan \& Co. And yet the auditor appeared to have escaped without censure or penalty. An Opposition MP Lim Kit Siang in a speech in the Parliament in June 1979 argued (Siang, 1982, p. 266): "In other countries, such negligence and conflict of interest could have resulted in professional action being taken against the firms of auditors, and I want to know what action has the Government taken against Kassim Chan \& Co. for its professional negligence and conflict of interest, leading to such colossal losses". He also claimed (p. 265) that the role played by the auditor in the "Great Bank Rakyat Betrayal" as one of the "sorriest episodes" of all.

From interview conducted with one of the leaders of the MACPA, it was found that except for the MACPA which suspended the membership of the audit partner in charge for "three months", it appeared that (as far as he knew it) the government authorities in the form of for example the Attorney General or the police had taken no action against the auditor in consequence. Even the ministry of finance had failed to withdraw his audit license. As for the MIA that did not even have the right machinery in place in the form of investigative and disciplinary committees, there was nothing to be expected of it. In fact, in the MIA 1967-1987 Annual Report, this very auditor was listed as an MIA council member since 1972. In other words, when the Bank Rakyat case became public and he was named in the Parliamentary White Paper for failing to do a proper audit and lacking independence, he not only did not face anything untoward from the MIA, but also continued to act as a council member of the MIA, as if nothing had happened! 
If for the 1970s, the May 13th 1969 Tragedy and the subsequent implementation of the NEP had pushed the government to get heavily involved in the nation's economy, now in the 1980s, the two economic recessions in the first six years of the decade and the financial debacles of numerous companies including those owned by the government forced the government to turn to the private sector to take over its role as the engine of the nation's economy. Therefore, where before growth was based on expansionary public expenditure, from the late 1980s onward most of the economic growth was to be due to private sector activities - with perhaps the expected inevitable impacts on the nation's audit practice.

\section{Accounting's Rejuvenation with the End of the NEP?}

There were two economic recessions experienced by the country during the 1980s. The first one was mild and took place in 1981-82 when the rest of the world also experienced recession. In response the government embarked on a number of strategies to stimulate the economy (Yan, 1994, p. 314; Abdullah, 1986). These efforts did not bear much fruit when later the economic slowdown in the industrialised countries impacted on the then fragile Malaysian economy. Thus, another recession took place in 1985-86. This recession was marked by reduction in national income, government revenues, consumer spending and investment and the worst that the nation then had to face since independence (Mohd.-Salleh, 1994, pp. 622-623). At its wake, the government intensified its efforts to attract foreign investors to the country's manufacturing sector. Thus, almost all NEP requirements were waived for export-oriented manufacturing industries. There was the de-emphasising of the restructuring prong of the NEP, ${ }^{\mathrm{xxv}}$ which led to a more liberal treatment of private enterprise, especially direct foreign investment, and a softening stance towards restructuring the ownership of share capital of companies and raising the threshold for manufacturing companies so that they escaped the net of the Industrial Coordination Act (ICA) (Zainal-Aznam, 1994, p. 597). Thus, the NEP had to some extent come to an end around this time and not in 1990 as planned in the early 1970s.

With a few facets of the NEP pretty much set aside and the private sector was now to play the role of the engine of the economy, the government began a series of programmes to facilitate the expansion of private sector business. These included the implementation of various strategies to upgrade the operation of the KLSE (see Azham, 1994) and a major amendment to the Companies Act 1985 in the second half of 1980s. The former had apparently helped in ensuring the KLSE to grow by leaps and bound in the late 1980s (see Kuala Lumpur Stock Exchange and Malaysian Strategic Consultancy Sdn. Bhd., 1992, pp. 28-29) and also later in the first half of $1990 \mathrm{~s}^{\mathrm{xxvi}}$. However, the major amendment to the Companies Act seems not to have provided any significant difference in the manner that audit is practised in the country. The same may be said on the revival of the MIA in 1987. This and more are discussed next.

Companies Act's Amendment. In 1985, the Companies Act was substantially revised (Sum and Wishart, 1989). Apparently the aim among others is to attract foreigners to invest in the country, through placing greater emphasis on the need for those associated with companies to be more accountable, and to provide greater protection for minority shareholders, who would include these foreigners. The revised Act which became effective from 1 February, 1986 made extensive changes to the existing Ninth Schedule to incorporate those elements that are regarded as best accounting standards and practices leading towards a much higher disclosure level than previously. When it concerns auditing in particular, the 1985 amendment requires for the first time all public accounting firms and the individual partners of such firms to register with the Registrar of Companies (ROC). Each partner is allocated a number that must be cited in all audit reports. Also, the amendment increases the range of persons excluded from acting as auditor. It appears that the purpose of this provision is to catch company secretaries operating as auditors (Phenix, 1986, p. 12). In addition, the term of an audit license is reduced from three to two years and the procedure of granting licenses overhauled to make it a more effective method of monitoring and policing standards of auditing. 
Finally, an auditor is required to report to the ROC if he or she were to find that there has been a breach or non-observance of any provisions of the Act. The onus is on the auditor to justify why he has not reported a breach of the Act to the Registrar. This seems to be a major break with the tradition in Malaysian Company Law based as it is on the British system, although it is contained in the corresponding sections of the Australian and Singaporean Acts. Failure to report could result in a requirement for the auditor to justify in a court of law his or her opinion that the breaches have been otherwise adequately dealt with by either one of these two approaches: by a comment about such matter in his or her audit report or by bringing the matter to the attention of the company directors. The fulfilment of either of these two approaches ensures that the reporting duty of an auditor to the Registrar is a limited one. Nevertheless, the significance of this requirement is that Malaysian auditors are now provided with a channel to report non-observance of the Act. Previously, the auditor could only use the audit report and by the time the report is presented to the members of the company, the damage caused by the transgressions might well have been irreparable. Section 174(8) of the Act also makes it clear that the auditor making the report would be protected by the law.

This particular 1985 amendment to the Companies Act 1965 has increased the auditor's statutory responsibilities in certain respect but at the same time provided the auditors with some additional protection. But with or without the protection, it appears that the auditors as represented by the MIA are not that happy with the additional reporting responsibility. This was openly remarked by the MIA president in a seminar. He mentioned (Hanafiah, 1990, p. 10): "In recent years this legislative intervention in the area of disclosure of certain matters to the regulatory authorities seems to be the trend. It is hoped that the public perception of the accountants' independence is not impaired as a result of such legal interference in the accountant-client relationship."

Perhaps more important than whether or not the auditors are happy with the additional reporting responsibility concerns the question of whether auditors who show their failure to abide with the reporting duty to an external party have in fact been taken to task by the authorities through criminal charges of fraud/conspiracy. To the present time there has been no news of such action by the government. But what had got into the news took place in the early 1990s when the then minister of domestic trade and consumer affairs had noted the following in a conference after saying that auditors had moral and legal responsibilities towards shareholders to report any irregularities to the authorities (NST, 29 Jan. 1991): "My ministry cannot implement and enforce the relevant laws effectively without the feedback and co-operation from your members. For your information, in the past five years the Registrar of Companies only received two reports under this section." The following year, he mentioned (NST, 17 Dec. 1992): "Auditors are still avoiding their responsibilities under the law to report any breach or non-compliance of the Companies Act 1965 to the Registrar of Companies." He also said that although only a handful of such reports had been received from the auditors, the ROC's inspection and enforcement work had revealed that a lot more companies had failed to comply with the law. He gave warning to the auditors that "appropriate action" would be taken against those who did not carry out their duties conscientiously. He said that the law - Section 174(8) - had made it clear that auditor who had failed to make such report was liable to spend two years in jail and/or pay RM 30,000.

MIA's Revival. Though interviews provided very confusing picture of the reasons and parties involved in the activation of the MIA (see Azham, 2002), the available documents were very clear in saying that it was the government which wanted the MIA to be active so that it can play the role of the national accounting body as envisaged by the Accountants Act 1967 (Akauntan Nasional, July 1992, p. 5; Berita Harian, 13 Jan. 1988). The exact reasons for the MIA to be activated and the important role played by the government in ensuring the activation were revealed in the "MIA 1988 Bounded Document". It was stated (pp. 5-6) that when the then federal cabinet rejected the MACPA proposal for the merger of the MACPA with the MIA, ${ }^{\text {xvii }}$ the MIA was "directed" by the government to be active. The document went on to state that the government did so because of the state of the then accounting profession reflected in various financial scandals which resulted with a loss of confidence in 
the profession among the general public and foreign businessmen. This document also pointed out that the government would like the MIA to be activated due to the proliferation of unqualified accountants who had caused the government to incur millions of ringgit of losses as a result of their falsification of their clients' accounts.

Note also that the then finance minister on the night before the inaugural AGM of the MIA in 1987, had mentioned what appeared to be the goals set by the government for the MIA to achieve once it was revived (The Malaysian Accountant, Oct-Dec. 1987, p. 8): "As the Minister responsible for implementing the Accountants Act it is my hope that members of the Institute will make MIA an effective professional body responsible for looking after the professional standards, education and training and supervising over the professional conduct of members." xxviii He continued saying that cases of fraud in the corporate and financial sectors in the country had raised questions on the function played by the auditors. He pointed out that the auditors owed professional duty to the investing public to point out any illegal activity in the company and come out with appropriate audit reports. He stressed the following picture of what the government envisaged for the accounting profession: "As for the government, it would like to see an accountancy profession that is capable of providing professional work of the highest standard in serving the various needs of the sophisticated business community and to earn the trust and respect of society."

Though these remarks point clearly the role and responsibilities of the MIA after its activation, it is quite difficult to say that overall the MIA in its first decade of being active has been successful in fulfilling them. In fact, it can be argued that the MIA has failed to achieve much as a regulator of the profession. Instead it has been preoccupied with various efforts to promote the profession. These and more are discussed next.

Regulatory Failure. The fact that since the early 1980s white-collar crime in its various forms has proliferated in the country is well known (see Koon, 1994). Right after the MIA was activated, it appears that various parties in the country have made their feelings known that they would like members of the accounting profession to conduct themselves with professional integrity. Among these speakers, Datuk Paduka (later Tun) Daim Zainuddin and Tun Ismail Ali had in fact mentioned the MIA by name as the party to play the necessary role in this field (see endnote number 2). Indeed, it was none other than the MIA president himself who concurred with the idea of the important role to be played by the MIA in this matter. On the night before the MIA's first AGM in 1987, the MIA president mentioned what he continued to repeat over the next three years: the MIA aimed to be a strong regulatory body (see MIA 1988 Annual Report, p. 6; MIA 1989 Annual Report, p. 7; Hanafiah, 1990, p. 15). Specifically on that night in 1987, he said (The Malaysian Accountant, Oct-Dec 1987, p. 10):

Speaking of image, the Institute must endeavour to restore the credibility the profession has lost in the eyes of the public. Several corporate failures such as the recent co-operative scandal can be attributed to apparent audit failures. These must be pursued and investigated by the Institute to discipline those members who have been negligent and to clear the names of those who were not. Only the MIA can do this as it has been endowed with such disciplinary powers encompassing the whole profession under the Act.

He stressed that after the inaugural AGM when MIA was then able to form its investigation and disciplinary committees, the council would have to make "a determined effort" to clean up the image of the profession. The MIA president even mentioned that to ensure a more effective policing by the MIA in the future there would be joint investigation and disciplinary body comprising representatives from the Treasury, Registrar of Companies and Registrar of Cooperatives. He had also volunteered to have the MIA to take over the "policing" task over the auditors handled by "a monitoring committee" in the finance ministry.

With this apparent early desire to be a strong regulator, a few months after the MIA first AGM, The Malay Mail (13 Jan. 1988) reported that following complaints against 15 accountants lodged by companies, fellow accountants and government departments, the MIA was going all out to clean up the act of errant accountants. The MIA president was reported 
to have said that 15 accountants were under investigation for alleged malpractice and criminal breach of trust. He also said that the accountants faced being de-registered while prosecution in court awaits those who had violated the Accountants Act 1967. And in 1988 and early 1989, there were a number of reports in the NST on what the MIA leaders would do to errant members. The headlines of the news reports said all: "MIA May Expel Members Who Break the Rules" (21 June 1988); "MIA Warns Members of Stern Action" (15 July 1988); "MIA May Expel Those Abetting Fraud" (17 Oct. 1988); "MIA to Haul Up Accountants Not Following Rules" (28 Feb. 1989). Also on 14 July 1988, reports with the following headlines appeared: "Warning from the MIA" (Business Times) and "MIA to Get Rid of Black Sheep" (The Star). In the former, the MIA president was reported of saying that the MIA would not condone members who "... persistently refuse to comply with the statutory requirements, accounting and auditing standards adopted by the Institute."

But later after the MIA's code of ethics was made effective in April 1990, hardly anything like those stated above had come out from the MIA. ${ }^{\text {xxix }}$ And if a check were to be made of the MIA Annual Reports over the years, one would discover that since the first AGM in September 1987 until the AGM in 1996, the MIA's disciplinary committees had only taken disciplinary actions against members for the years 1987/88, 1991 and 1992. In other words, in the later years after its activation, it appears that the MIA had not found it "fit" to discipline any members where complaints were filed against. Specifically, for the years 1987/88, 1991 and 1992, four members were disciplined by the MIA each year for a total of 12 members in its first ten years of active life. ${ }^{x x}$ Since 1993 to the AGM in 1996, it had failed to impose disciplinary actions against its members although the MIA Annual Reports showed that "every year" since 1987 (except for the years 1989 and 1990 when not much details were disclosed in the MIA Annual Reports on the works done by its investigative and disciplinary committees ${ }^{\mathrm{xxxi}}$ ) the total number of cases investigated, under review or pending have in fact reached 25 (1996), 30 (1995), 25 (1994), "more than ten" (1993), 29 (1992), 28 (1991), 39 (1990) and $23(1987 / 88)$.

Related to the topic of failing to ensure that its members are in fact doing a better job as accountants or auditors and that necessary actions are taken against the errant ones, the MIA has also failed to implement the very ideas that its leaders themselves claimed needed to be put into action in order to strengthen the nation's audit practice. One of these ideas concerned the practice of quality review of the audit firms. The MIA 1992 Annual Report (p. 7), Mingguan Malaysia (12 Apr. 1992), Akauntan Nasional (May 1992, p. 26; Nov/Dec. 1992. p. 31; June 1993, p. 22), NST (28 July 1992) and finally the MIA 1993 Annual Report (p. 15) had the MIA leaders given glowing details of the need for a quality review programme. Interviews with a number of the MIA council members had produced conflicting stories why the MIA has failed to implement it. Another area that the MIA had failed to put into action is concerned with its various proposals in 1992 related to the subject of the auditor's independence which the MIA president claimed "ought" to be implemented with a few other measures to strengthen the profession (Akauntan Nasional - Conference Times, 15 July 1992, p. 1; Business Times, 15 July 1992). Note the following remark that he made when talking about the various proposals (Akauntan Nasional, 15 July 1992): "There is no strong financial centre in the world that is not supported by a strong and well developed accountancy profession. Therefore now is the time for action. Now is the time for us to develop ourselves and to give our profession a lift."

Also, in at least one case the MIA had appeared to go weak upon its earlier fine effort. This is concerned with the Continuing Professional Development (CPD) that was made effective from 1 March 1992 (Akauntan Nasional, March 1992, p. 22). See the Akauntan Nasional (Nov. 1990, p. 20), NST (6 Nov. 1990) and Akauntan Nasional (Nov/Dec 1992, pp. 30-31) where the MIA president stressed why the MIA needed to have the CPD made compulsory. But the MIA 1995 Annual Report (p. 26) disclosed that "changes" that were introduced in November 1994 and made effective from 1 January, 1995 ensured that what took place in the past, where the MIA secretariat was the entity responsible for CPD record-keeping, was replaced with members themselves made responsible to do the record-keeping individually. There is no more need for each member to submit an annual CPD report in a prescribed form. 
Instead, members would be selected at random and asked to produce evidence of compliance.

Successful Promoter. After its activation, the MIA had shown the tendency to give great interest to promote the interest of its members in a number of ways. In October 1988, the MIA submitted a memorandum to the finance minister requesting the government to look into the desirability and possible methods of limiting the accountant's personal liability for negligence claims. The government had not bothered to respond to this MIA's proposal. As if the government's indifference was not embarrassing enough and notwithstanding the apparent positive state experienced by local auditors, the MIA had also on 30 January, 1991 launched a professional indemnity insurance scheme for its practising member (Akauntan Nasional, July 1992, p. 6). But the MIA had failed to get good response from its practising members. After nine months, only 10 percent of the some 800-member firms had signed up (NST, 30 Sept. 1991). Thus, the MIA president said that the MIA council would have to consider making it mandatory for all member firms to be covered by the scheme (NST, 19 Oct. 1991).

The MIA in what appears to be an all out effort to protect its members' public accounting activities had also started early in 1988 a fight against the unqualified/unregistered accountants. From February to November 1988, the MIA resorted to the lodgement of police reports and at times the MIA senior staff members would join the police to raid the premises of these unqualified accountants. The MIA also hired lawyers to bring the matter to court. By the end of 1988, MIA had lodged 92 police reports and the police had raided 19 firms (NST, 5 Nov. 1988). This approach taken by the MIA received a certain level of condemnation from various parties. For example, the Editorial to the Business Times (5 March 1988) had noted the following: "Until MIA comes out with its own examinations to allow these unregistered accountants to gain local recognition too, it is argued that such a tough stance may not be entirely fair." The crackdown ended when Malaysian Institute of Corporate Secretaries and Administrators (MICSA) representing the unregistered accountants sent a letter of appeal to the then finance minister for a review of the actions taken by the MIA (NST, 5 Nov. 1988). Later in 1992 the MIA launched the Malaysian Association of Accounting Technicians (MAAT) to house most of these accountants - a move that with hindsight did not need the MIA to initiate such a crackdown in the first place. That was precisely what the MIA president claimed in 1989. He said (Akauntan Nasional, Sept. 1989, p. 24): "... with the benefit of hindsight and the number of bogus accountants involved which is estimated at some 3,000 - the Institute should have formed the proposed Malaysian Institute of Accounting Technicians (MAAT) first."

Finally, the MIA in promoting the accounting profession had also proposed institutionalising its minimum audit fees schedule (see MIA Council, 1994). The new ruling that governed all MIA practising members was supposed to be effective from 1 January 1992 (Akauntan Nasional, Feb. 1992, p. 19), but it was later moved to 1 April 1993 (Akauntan Nasional, May 1993, p. 16). At the end it was turned into a mere "guideline" as of 1 September, 1994. This was because as soon as the minimum fees schedule was implemented, the uproar began. The Perak Chinese Chamber of Commerce president suggested that the MIA deferred its proposal to implement its minimum audit fees schedule on 1 April, 1993 (NST, 17 Feb. 1993). He claimed that the MIA minimum audit fees were too high and unfair and would be a burden for small and medium businesses. He stressed that the government should amend the Accountants Act of 1967 to prevent such exploitation of small businesses by MIA. The following year, the Federation of Malaysian Manufacturers (FMM) issued a statement urging the MIA to review the audit fees schedule (NST, 18 Feb. 1994). The final showdown took place on 19 January, 1994 when the Associated Chinese Chamber of Commerce and Industry Malaysia (ACCCIM), FMM and MIA plus a few other interested parties met the domestic trade and consumer affairs ministry officials including the ministry's secretary-general to discuss the new fees structure (NST, 11 Feb. 1994). A few months after this meeting, the MIA president announced that MIA would drop its minimum scale of audit fees effective 1 September, 1994 and instead maintain it as a guide for its practising members (NST, 2 Aug. 1994). 
It may not be an exaggeration to say that the MIA after its activation did not seem to provide much confidence that it was able to regulate itself well. This seems to illustrate what Friedland (1989, p. 74) says to be "the tremendous reluctance" across accounting professional bodies in the Far East to prosecute their members. The MIA had also failed to implement certain projects that its own leaders argued were necessary for strengthening the nation's audit practice. As if these were not terrible enough, the MIA in the related field of raising the number of qualified accountants/auditors had shown that its conducts had left much room for improvement.

Remarks made by a newly appointed finance minster (Akauntan Nasional, Sept/Oct 1991, p. 23; The Malaysian Accountant, June 1992, p. 18) and by the MIA itself (ASEAN Accounting Research Unit, 1992, p. 75; MIA 1992 Annual Report, p.16) gave evidence that the country was facing a shortage problem of qualified accountants/auditors. In the NST (12 Apr. 1991), the following was also stated: "A Malaysian Institute of Accountants (MIA) document says the shortage of auditors and tax consultants is very acute. While there are over 172,000 companies registered with the Registrar of Companies, there are only about 600 approved company auditors." But the MIA from the time when it was activated had kept on shifting the date as to when it would start organising the professional examinations! ${ }^{\text {xxxii }}$ And when the examination was finally set up in 1996, the MIA did not actually provide a real alternative or an actual additional avenue for locals wishing to qualify as accountants because it was a combined effort of both the MIA and the CACA (Akauntan Nasional, Oct. 1995, p. 4). The collaborative exam structure was exactly the same as the UK based qualification which had been offered in the country for decades. The difference between the two examinations is that students now had the option of sitting for the UK or Malaysian law variant papers.

All in all, the MIA during the ten year period following its activation in 1987 had largely failed to bring much confidence in its role as audit regulator. Unfortunately, the authorities did not seem to do much to help improve matters. From several documented sources, it seems that the government was not happy with the MIA during the first few years after its activation and had in fact initiated some actions but never brought those to fulfilment. The government's half-hearted reaction to the MIA's self-regulatory failure in particular and the quagmire in the profession in general may be seen in speeches delivered by the then deputy finance minister Loke Yuen Yow in July 1988 (as found in Appendix 12 in the "MIA 1988 Bounded Document") and later in 1990 (Akauntan Nasional, Oct. 1990, p. 21) and also in the speech by the then finance minister, Tun Daim Zainuddin, in September 1989 (Akauntan Nasional, Sept. 1989, pp. 21-23).

After the finance minister stepped down in 1991, it seems that not much could perhaps be expected from his successor. As a whole, the person who replaced him who was also holding the post deputy prime minister had not been critical of the performance of the MIA as a regulator. In fact, he seems to have a high regard in Malaysia's audit firms and the related standard of financial reporting of Malaysian companies (see Akauntan Nasional, Sept/Oct 1991, p. 23; The Malaysian Accountant, June 1994, p. 14). Since he took over from Tun Daim Zainuddin, only once - in the very year when he got hold of the post - that he acted critical of the audit executed by local auditors. At the 7th National Accountants Conference, he mentioned that the government viewed the lack of credibility of the auditors as a serious matter since there were among them those who had followed the instruction of the company directors or top management of the companies to ensure that the financial statements reflected misleading picture of the company affairs (Utusan Malaysia, 19 Sept. 1991).

It may be safe to say that the economic recessions of the 1980s had to some extent disrupted the pre-existing political, corporate and financial systems in Malaysia. It had also created a perceived need for "structural" (as oppose to in-depth) changes to the audit system. The fact that changes in the audit process stressed more on form or appearance but not so much on substance had ensured that not much could perhaps be expected from the auditors and their representative accounting body the MIA. The next section attempts to provide an answer as to why Malaysia had been so unfortunate in the audit arena. 
Towards Understanding Audit in Malaysia

2014, Vol. 4, No. 4

The objective of this paper is to explain the distinctive audit phenomenon in Malaysia through tracing the historical development of the audit function from 1957 to 1997 and analysing the environmental influences on this development. In the previous section, the delineation of what took place in the audit arena over the forty year period is divided into three parts. These three parts may now be collapsed into two eras: pre-NEP and NEP Plus. Both periods have given evidence of the relevance of the theory of political economy of accounting.

Audit During the Pre-NEP era. During the pre-NEP era, the passing of the Companies Act of 1965 and the Accountants Act of 1967 appear to signify that the economy was being set up to operate under the laissez-faire kind of environment by the government - with the assistance of the private sector as shown by the formation of the MACPA in 1958. The authorities and other parties made the necessary moves to ensure the existed foreign investments stayed put and that much more could come into the manufacturing sector. The Parliamentary Debates (Vol. II, no. 8, Col. 1558 dated 9 Aug. 1965) had stated specifically that the Companies Act 1965 had two objectives: to protect investors and to attract "foreign investors" into the country. Specifically, it was in the interest of foreigners who were shareholders and bankers to the merchant agency houses that the right audit infrastructure needed to be in place.

These foreigners were those who controlled the nation's modern economy then - just like what happened prior to independence. In 1953, 700 European-owned estates in the Malay Peninsular were managed by 20 managing agencies, of which 11 were merchant houses (Puthucheary, 1960). In addition, about 25 persons, some of whom were directors of merchant houses, sat on the boards of directors of nearly 200 rubber companies which owned nearly a million acres of rubber plantation. As for tin mining, in 1954 three managing agencies had vast authority over tin production. These were Anglo-Oriental (40), Neill and Bell (14) and Osborne and Chappel (10) which managed 64 of the 108 dredges in the Malay Peninsular on behalf of a total of 47 companies that accounted for 73 percent of total European-owned mining output (Jomo, 1986, p. 173). Also prior to the nation's independence, in 1955,60 percent of the peninsula's imports and between 65 percent and 75 percent of its exports were in the hands of British trading firms (Puthucheary, 1960, p. 75). Later, at the time of independence in 1957, the estates managed by the agency houses occupied about 65 percent of the entire cultivated area of Malay Peninsular. Also, several years after independence, in 1965, three mining agencies, Anglo-Oriental (11), Osborne and Chappel (10) and Associated Mines (4) controlled the operations of 25 of the 43 public-limited tin-mining companies (Djojohadikusomo, 1968/69, p. 171). Some of these mining agencies were subsidiaries of the British-based holding companies.

When it concerns the manufacturing sector, in 1959, the top 156 companies accounted for more than half of all sales and employed about a third of the sector's labour force. Foreigners - those with residences overseas - owned half the share capital in the top 83 companies (Wheelwright, 1965). A decade later, the widespread ownership of manufacturing companies by foreigners continued. Lindenberg (1973) pointed out from his 1968 data that 77.1 percent of shares in pioneer firms were held by foreigners. This percentage was greater than the 59.6 percent foreign share in manufacturing as a whole in 1970 (Mid-Term Review of the Second Malaysia Plan, 1973, p. 83, Table 4.7). See also Hirschman (1983).

By the early 1970s, about 60 percent of the share capital of limited companies was owned by the British; in agriculture and fisheries, it was as high as 75 percent; in mining and quarrying about 72 percent; and in commerce and manufacturing, it was 63 percent and 59 percent of total share, respectively (Tun Hussein Onn Speech, 20 Feb. 1974, as found in Pillai, 1984). This last set of numbers could support a claim that, more than a decade after the so-called independence, Malaysia was only independent in form but not in substance. Especially from the economic point of view, it was still shackled to Britain. Not suprisingly, the most significant events with potential to affect the development of auditing, namely the passing of 
the Companies Act 1965 and the Accountants Act 1967 and the creation of MACPA appeared very much to be "instruments" for the furtherance of the status quo brought forward from the time prior to the independence.

With the eruption of violence between Malays and Chinese in 1969, the Malaysian economy changed direction away from a full free enterprise economy to that spearheaded by the government. And even after the NEP was supposed to come to an end in 1990, the nation's economy continued to be much in the hands of the government or those who are closely associated with it. In consequence, the picture that emerged showed that to a very large extent audit has little rationale for existence. In other words, the sorry picture of audit from the 1970s onward provides evidence of the minimal value of auditing in Malaysian society. To paraphrase Hopper et al. (1987), auditing development has been implicated in broader ideological and political struggles in the society.

Audit in the NEP Plus Era. From the early 1970s with the launching of the NEP until perhaps the mid-1980s when the government was forced to give a second look at the NEP due to the occurrence of the 1985-86 economic recession, the one word perhaps able to describe the audit practice was its apparent "neglect" by the political executives. During this period, with the MACPA thriving and the presence of the audit section in the Companies Act, it appears that the nation leaders saw no further need to focus on the audit system. Examination of what took place within the audit arena whereby the accounting statutory body MIA was left inactive leading to a number of negative repercussions demonstrates a lack of concern for seeing that audit and related areas should function appropriately by those parties involved in their administration.

This could possibly be due to the direct access to internal financial information and to the corporations' directors by those who were from the government side who were now also played the role of shareholders. Such access subverted any strong demand for a truly functioning audit and related matters. The direct and indirect access to information apparently reduced a potential for agency problems except for those deemed to be outsiders. But when these outsiders were mainly speculative investors, they seemed to show that they "accepted" information asymmetries.

The authorities might have also failed to improve upon the audit functioning due to the fact that they did not want the accounting practitioners to make their life unnecessarily difficult given the "underhand" acts that they committed (or had to commit) to ensure the goals of NEP (and/or "their own") were fulfilled at "whatever" price. This very point was made clear by the leader of Aliran, the NGO for "freedom, justice and solidarity" in Malaysia, Chandra Muzaffar when he tried to explain the reluctance of national leaders to act on those responsible for corrupt activities (Chandra, 1989, p. 99). ${ }^{\text {xxiii }}$ He wrote: "To expose their misdemeanours would be to expose the New Economic Policy's not so subtly concealed agenda of creating Malay capitalists, whatever the costs and the consequences. Ethics have to be set aside for the time being - so it has been argued in certain official circles - to facilitate the rapid growth of a Malay capitalist class."

Overall, audit in Malaysia during the NEP era was in an uncertain and unsatisfactory state. Unfortunately, the situation had not really improved much even after the NEP came to an unofficial end in 1985. Although this time period saw the revival of the MIA in 1987 and the Companies Act 1965 heavily amended in 1985 resulting in additional duties and responsibilities for accountants and auditors, the audit transformation might be safely said to be superficial. Specifically, the actions of MIA in the regulatory field and the implementation of the auditors' ROC reporting duty under the amended Companies Act were below expectations. And yet there did not seem to be any decisive efforts on the part of those with power to see that these were improved.

This could be because of the fact that by late 1980s and early 1990s, even after a significant proportion of the economy had been transferred - under the so-called privatisation exercise from the government to the private sector needing what was proclaimed to be a strong accounting profession, what appears to be the case was that much of the private sector was 
still in the hands of those associated closely with the government sector (see Gomez, 1997; Jomo, 1995). This section of the private sector may even be considered as an "extension" of the government sector where reigning politicians and their political parties had for years been deeply involved in the business sector (see Gomez, 1994, 1990; Leigh, 1992; Leong, 1988, Chapter Six; and Gale, 1985). There was merely a superficial rearrangement of wealth and thus power among the few in the society. It is also notable that when it concerns the listing of a number of privatised entities at the KLSE, the percentage of shares offered for sale did not reach above thirty percent of the total shares (Mohd.-Sheriff, 1992): MAS, 30 percent; MISC, 17 percent; STM, 23.9 percent; and TNB, 22.8 percent. Therefore, through partial divestment of equity of government-owned entities, the government was still in the case of these companies, their major shareholder.

This very fact is not surprising since the local corporate scene was filled with individuals or companies owning at least 51 percent of the shares of the so-called public companies including those listed at the KLSE. So, even in the 1990s when the NEP was supposed to have come to an end, the NST (30 May 1994) reported that more than two-thirds of the 335 companies on the main board and all of the 92 on the second board were controlled either by one or a few shareholders with more than 51 percent of the shares. This domination was not illegal since the KLSE listing rules required no more than a public float of 25 percent of the total shares issued. Therefore, the listed companies still remained as private companies (Mohd.-Salleh, 1989). They were public and listed only in names. Many of the listed companies were labelled by chairman of the Malaysian Institute of Economic Research (MIER), Datuk Dr. Kamal Salih, as "private-owned public company" (NST, 21 August 1991). Most shares were still held by insiders - family members, friends, clan members and others known personally to the companies' founders. And when it concerns the privatised entities including those listed at the KLSE, the shareholders were other government entities.

Therefore, in the whole, the "principal-agent" dichotomy did not exist or was at best blurred in the Malaysian context. Even though more and more companies were formed from the 1970s onward, ${ }^{\text {xxiv }}$ many of them were "companies" merely in name - leading to various distressful conducts perpetrated by majority shareholders who also managed their daily affairs. The unsavoury acts of these companies included the tendency to flout the law (Ram, 1985; Azham, 2002) and the reluctance to disclose much (Tong et al., 1989; Tong and Ann, 1996; Tay, 1994; Jaafar, 1992). Thus, the need for a truly functioning audit was still not as acute as would be expected if indeed a new political economic context had emerged after the two recessions in the 1980s. In fact, it appears that a weak audit profession that devoted more attention to promotional aspects than regulation suits certain parties, notwithstanding the rhetoric by a few among the power elite stressing from time to time the need for improvements in practice, stricter enforcement of rules and regulations, etc.

It is a fact that for auditing to reach its potential requires transparency in conduct, and a situation in which those making decisions can be held accountable. All these requirements did not fit the Malaysian environment as succinctly described in mid-1997 by the Editorial to the NST (7 June 1997):

At the pace of its economic growth, Malaysia, too will feel the vice of corruption sooner or later. Like others before it, this country will also try to look the other way, and do as much as it can to avoid rocking the economic boat. Like their Asian peers, politicians will trust to the moral superiority of a few good men to keep the others in line. And there is always the argument against washing dirty linen in public, the stubborn loyalty of politicians to their compatriots, and an equally obstinate belief that corruption is confined to an indiscreet minority. In politics, hard choices require courage and often pose uncertain risks - which is why politicians will try to postpone them until their hands are forced. The instinct of self-preservation will usually urge politicians to control the damage done by disclosures of corruption, rather than attempt to root it out. (Emphasis added.)

There were six reasons (in italics) disclosed by the Editorial why corruption could be considered to have gone unhampered, and as disclosed by the Anti-Corruption Agency, 
corruption had been on the rise over the last 20 years and stiffer punishment was needed (New Sunday Times, 8 June 1997). The people could not perhaps expect much from their accountants and auditors when their elected leaders did not seem to think that it was their responsibility to ensure that their "compatriots" were really conducting themselves with integrity. For one reason or another, the leaders acted with much leniency ensuring cases of corruption were swept under the carpet, and the auditors who might have incurred audit failures could expect in turn that they would be able to go scot-free everytime a business collapsed and financial scandal erupted.

Perhaps a good case in point is the "BMF Affair" that took place in the first half of 1980s that led to the loss of around US\$1 billion and the death of the (internal) auditor who investigated the case. Koon (1994) in her study of the BMF Affair pointed out what the government appeared to have done "to prevent" its public disclosure. On pages 194-95 of her thesis, she listed down the "systematic cover-up of the case from the Malaysian public" ranging from the denial made by the BBMB of the extent of subsidiary BMF involvement in the Carrian Group in September 1982 to the forming of a limited Committee of Inquiry by the government after rejecting public demand for a Royal Commission in January 1984 and finally to the government's reluctance to publish the report of the Committee of Inquiry in 1986. Later, due to public's pressure for publication, only 2,000 copies were published at the price of RM 250 which was beyond the reach of average Malaysians!

With all this in the background, it is perhaps not surprising to find that HRM as the auditor of the parent body BBMB was "quietly" replaced soon after by another auditor. This apparently was the worse that could happen to an auditor whose audit opinion in its audit reports was the opposite of the stance taken by the Committee of Inquiry which disclosed that both audited financial statements of $\mathrm{BMF}$ and $\mathrm{BBMB}$ did not give a true and fair view of the state of affairs of BBMB and the Group as at 31 December 1981 (Siang, 1986, p. 36).

This revelation on what took place in the "private sector" may be added to those that came straight from those in the know in the arena of government operation where the leaders had repeatedly proclaimed the need for clean government and stiff actions against corrupt. From the then deputy accountant-general (Akauntan Nasional, Jan. 1990, p. 19), he noted that the government operation had been indifferent towards accounting as a tool for effectiveness and efficiency. And from the former auditor-general, Tan Sri Ahmad Noordin, the following was his remark when he was discussing value for money audits in government operations (Ahmad-Noordin, 1986, p. 47):

We have accordingly amended or rather we had the Audit Act amended to ensure that the Auditor-General has the necessary power within the law to carry out this value for money audit as I mentioned just now. What seem to be the constraint when I was there was that as value for money or performance audit penetrates into the activities of governments, there is a natural tendency for the authorities having the power to approve the staff for the Audit Office to make it difficult for the Audit Office to get the necessary skills and manpower to carry out this work.

Thus, it may safely be said that the debilitating atmosphere in the audit arena in the post-NEP era had been deliberate and intended to deflect attention from creating a "culture of accountability" or full public disclosure, because interested parties did not want to face the unnecessary "complication" of explaining themselves to anyone in their pursuit of gaining economic ascendancy. This is as stated by Belkaoui (1974, as reported by Samuels and Piper, 1985, p. 141): a class elite in many developing countries are interested in maintaining secrecy, thus, the financial reporting system was purposely made to be weak so that it was easy for this elite to maintain secrecy for their own gain.

Specifically, in Malaysia, the MIA although it was revived in 1987, was not expected to emerge as a strong accounting body able to play the required role in confronting cases of corruption, nepotism and patron-clientelism that had been plaguing the country for many decades but particularly in the few years prior to the onset of the Asian Financial Crisis in 1997. In short, it was in the interest of certain sections in the Malaysian society to see a 
malfunctioning audit marked by an incapable accounting professional body and a weak enforcement of a company law section on auditor's reporting duty to ROC. Therefore, while the MIA council members appear to be ineffective and those overseeing the audit related sections of amended Companies Act had failed to play their role, others with the power to make corrections had not translated their words into actions.

This failure by the power elite to take the appropriate actions could also be traced in the case of the MIA-MACPA rivalry and that of the enforcement of Malaysian Accounting Standards Board (MASB) standards. Details of these two cases may be found in Azham (2002). See also Susela (1999). Briefly, on the former, the series of public disagreement between leaders of the MIA and MACPA had failed to force the authorities to make a stance as to which body that it saw as the leader of the nation's accounting profession (Malaysian Business, 16 Aug. 1988, p. 19; Malaysian Business, 1 Aug. 1996, p. 1). As for the latter, the establishment of the MASB by the government in mid-1997 to take over from the MIA the responsibility of setting accounting standards had failed in ensuring that it was equipped with the power of enforcement - though early on in 1994 (The Malaysian Accountant, June 1994, pp. 14-15) and later in the following year the then finance minister in his 1996 budget speech (NST, 28 Oct. 1995) did mention such a need. The failure to act accordingly could only mean that those with power were not really serious in seeing the emergence of a well-respected accounting profession and high quality financial reports.

For what appears to be an act of "too little too late" coming from the authorities, just several months before the country was dragged into the quagmire of the Asian Financial Crisis 1997-98, the ROC was reported to have sent its few officers scurrying around the country to check audit working papers of audit firms (Business Times, 21 Feb. 1997). The fact that this activity by the ROC which had never been conducted before (as found in an interview with the Companies' Registrar himself) happened to coincide with the efforts conducted by yours truly (to interview personalities such as the former finance minister Tun Daim Zainuddin and the Companies' Registrar) had led yours truly to conclude that there was more to this action of the ROC than what meets the eye. These accountants were supposed to complete their task at the end of the year. However, there did not appear to be any reported news of the outcome of their operation later the following year. ${ }^{\mathrm{Xxx}}$ In the interview conducted with the Companies' Registrar, he did state that the investigations had uncovered that some of the complaints that he received from various parties including shareholders on the "correctness of accounts" and "quality of auditing" were found to be valid. Furthermore, he said that it had been found that the MIA "had not carried out the task of regulating its members to the ROC's satisfaction".

Capitalism per se does not require external audit. This is especially the case when the capitalism one refers to is the cooperative, insider or crony type (see Kunio, 1988). The so-called independent audit is an antithesis to such economy. Thus, in Malaysia, one may find evidence where what may be considered a cornerstone for external audit is downplayed by those who should know better. In an interview taking place in 1988, Datuk Mohamad of the audit firm Hanafiah, Raslan and Mohamad (HRM) mentioned what took place in 1964, "when all the large accountancy practices in the country were owned and dominated by foreigners" (Malaysian Business, 16 Aug. 1988, p. 13): "The late Tun Razak (who was then the deputy prime minister and later prime minister) called the three of us [he and his two colleagues] in one day and said: 'Why don't you guys set up a local auditing firm? At least try. If you can't make it, we'll take you back'." Next he was quoted to say: "It was difficult decision to make .... [b]ut we were lucky to receive a lot of assistance from Tun Razak. Right from the beginning, big clients like the National Electricity Board (NEB), the Police Cooperative, the Social Welfare Department and many government-related statutory bodies had their accounts audited by us." When the 1970s arrived with the government played out a much bigger role in the economy, HRM being the only "Bumiputra accounting firm" around was hired to audit the burgeoning number of public enterprises and other government entities.

Note also that when it concerns the local Chinese auditors, the MIA's official journal, Akauntan Nasional (Dec. 1990, p. 18), had reported how some MIA members "with small 
practice" were having difficulty with the newly issued MIA's code of ethics related to the need for auditors to be independent. As a result, the chairman of the MIA's Ethics Committee, Khoo Eng Choo, noted the following (Akauntan Nasional, Dec. 1990, p. 18): "The Committee is more concerned with the auditors of public listed companies rather than with auditors of family companies."

All in all, in the absence of widespread stock ownership and less than a free market to allocate resources, monitoring of management operations can perhaps be provided by method other than external audit. Probably in Malaysia that has always been the case - though to what extent that such monitoring is done professionally is everybody's guess. Thus, by the time the nation experienced the damage brought by the Asian Financial Crisis 1997-97, audit in Malaysia could hardly be regarded as an intrinsic and constitutive component of the government of economic life. In other words, its presence to a good extent was devoid of meaning. Not surprisingly, the nation's audit arena was filled with lost hope and utter neglect. Just another story of the triumph of hope over experience that Malaysians are so used to.

\section{Conclusions}

Although there have been numerous studies such as those by Enthoven $(1977,1973)$ on the role of accounting in economic development and others such as the effect of international transfer of accounting skills (Seidler, 1967; Needles, 1976), accounting is constantly seen as a technical activity which provides financial information for economic development. The scholarly works are invariably normative and are deemed located in the functionalist paradigm. Thus, they fail to examine how accounting is very much a reflection of the society it is located in. There always appears to be a lack of attention to developing countries' socio-economic factors which impact upon accounting resulting in suggestions that the transfer of western accounting technologies and ideas would be unproblematic and undeniably and automatically beneficial to these countries - though experience time and again appears to prove otherwise.

The use of the theory of political economy in this paper in explaining the rationale for auditing in Malaysia should be able to address the issue of the lack of accounting studies in developing countries where accounting is regarded as a part of the wider socio-economic and political context. In other words, in the very notion of accounting propagated by Burchell et al. (1985) where the accounting processes and institutions are not so much influenced by the wider social, economic and political environments as "inter-twined" with them, and thus, as proposed by Hopper and Powell (1985, p. 93), need to be studied together.

The Malaysian audit story covering a period of the first forty years after independence in 1957 has provided evidence of the character of auditing as a social activity within a specific network of changeable social relations. It is embedded in its social, economic and political context. Time and again, factors surrounding audit have had an impact on the audit process itself. Audit in Malaysia therefore cannot be interpreted as simply a technical phenomenon residing outside the social domain.

From a practice originated as a consequence of the need perceived by the nation leaders in the late 1950s and 1960s to maintain status quo in the nation's modern economy, following the launching of the NEP in early 1970s, the function of auditing in Malaysian society was in most cases devoid of any essence of mission; instead, it was created, shaped and changed by the pressures which gave rise to its development over time. The role that it served was intertwined in the contexts in which it operated. As has been noted by Hopper et al. (1987), accounting development has been implicated in broader ideological and political struggles in the society.

During the first decade after independence compared to the next three points to the idea that audit played the stewardship role for the benefits of western investors. In the following three decades, this role continued to be valid for the limited number of companies involving foreign investment. But for the majority of the companies owned by government or its 
associates or those by the Chinese Malaysian, the audit in many cases appears to be around mainly because the law had ensured that that was the case. There was little to say of the presence of theoretical or inherent desirability of audit - as it is commonly seen in Anglo-American nations, as a necessary adjunct to improving the inherent usefulness of company reporting for shareholders and other users. Malaysia's fusion of national attributes and power arrangements had ensured that this would be the case.

In short, the basic structural purpose of audit in Malaysia as presented in several authoritative sources such as Company Law is really nothing more than to provide the "image" of a modern economy to attract investments from overseas. It is a kind of representation that is not supported by the reality on the ground for much of the nation's history after independence. Specifically, the changes occurring in the audit system since the first half of 1980s onward were more ephemeral than real, structural rather than in-depth. In other words, pressure for change was related directly to the creation of the modern audit infrastructure, and not to the need for its effective and appropriate administration in the Malaysian social environment. This is perhaps understandable since very little actually changes in the manner that political and economic power were distributed among members of Malaysian society in the context of the so-called change from a predominantly command-economic system in the 1970 s to a more capital-market economic system in the late 1980s and beyond.

All in all, it appears that the process of auditing was affected by certain groups who possessed special interests. These parties had made it certain for audit to operate in congruence with their expectations and objectives. And if changes were to take place, they would be mobilised in the pursuit of their vested interests. Armstrong $(1985,1987)$, Hopper et al. (1987), Lehman and Tinker (1987), Loft (1986), Miller and O'Leary (1987) to mention a few have stressed this very point. Notwithstanding their rhetoric, it may safely be said that they had little interest in seeing changes in the status quo. As Rohwer (1995, p. 281) in his acclaimed work on the rising of East Asian nations had noted, "... elites do not normally reform themselves or do things to threaten their own position".

Overall, audit in Malaysia prior to the onset of the Asian Financial Crisis 1997-98 was in an uncertain and unsatisfactory state - similar to those found in other Asian countries such as the Philippines (Dyball and Valcarcel, 1999) and Japan (Sakagami et al., 1999). It was clearly influenced by the broader context in which it was embedded. It was the result of historical events which, on the face of vested interests and distinctive social, economic and political attributes, had failed to ensure that its existence in recent years would really be a big difference to the pre-existing arrangement which emerged in the early 1970s with the launching of the NEP.

In conclusion, it is perhaps safe to say that to figure out the probable value of an activity such as auditing in a society, the direction to be taken needs to be historical, contextual and subjective. Anything less appears to bring an inadequate outlook that may well be more confusing rather than enlightening for interested parties. Also, by understanding audit functioning from the perspective of the theory of political economy, it may be viewed as satisfying a need for research in financial reporting in developing countries where the supposedly technical tool of auditing is seen to intermingle with the various factors in the environment. Accordingly, it should lead to a broader if not an alternative conception of auditing compared to that written from a functionalist perspective in a normative manner. Future research should employ this approach to study the development of auditing in other countries. This should enhance understanding of the underlying character of auditing in different countries and assist consideration of the appropriateness of auditing harmonisation at the international level.

\section{Bibliography}

Abu-Hassan, K. (1986), Public Accounting and the Accounting Profession in Malaysia, paper presented at the Universiti Utara Malaysia's Professional Lecture Series, October, Universiti Utara Malaysia, Jitra. 
Ahmad-Noordin, Z. (1981), "Proposal for the Establishment of A National Institute of Public Finance and Accountancy", The Malaysian Accountant, Vol. 2 No. 1, pp. 25-28.

Ahmad-Noordin, Z. (1986), Value for Money Audits - The Practical Aspect, in Proceedings for the MIA and MACPA jointly organised 5th ASEAN Federation of Accountants Conference, 4-6 November, Kuala Lumpur.

Aliran (1981a), Aliran Speaks: Being a Collection of Aliran's Views on Various Social Issues From August 1977 to September 1981, Aliran, Penang.

Aliran (1981b), Corruption, Aliran, Penang.

Aliran (1988), Issues of the Mahathir Years, Aliran, Penang.

Armstrong, P. (1985), "Changing Management Control Strategies: The Role of Competition Between Accountancy and Other Organizational Professions", Accounting, Organizations and Society, Vol. 10 No. 2, pp. 129-48.

Armstrong, P. (1987), "The Rise of Accounting Controls in British Capitalist Enterprises", Accounting, Organizations and Society, Vol. 12 No. 5, pp. 415-36.

ASEAN Accounting Research Unit (1992), The Auditing Framework in ASEAN, School of Accounting and Business Research Centre, Nanyang Technological University, Singapore.

Azham, M.A. (1994), Accountability in the Audit Profession in Malaysia, University of Malaya Press, Kuala Lumpur.

Azham, M.A. (2002), Ethnicity, Foreign Investments and Strong Pragmatic Government: Towards Interpreting Accounting Progress in Malaysia, paper presented at the Universiti Teknologi MARA organised Conference on Financial Reporting: Issues in the $21^{\text {st }}$ Century, $29^{\text {th }}-30^{\text {th }}$ October, Shah Alam.

Bass, J.R. (1973), Malaysian Politics, 1968-1970: Crisis and Response, unpublished PhD Thesis, University of California, Berkeley.

Brennan, M. (1985), "Class, Politics and Race in Modern Malaysia", in Higgott, R. and Robison, R. (Eds), Southeast Asia: Essays in the Political Economy of Structural Change, Routledge and Kegan Paul, London, pp. 93-127.

Briston, R.J. (1978), “The Evolution of Accounting in Developing Countries", International Journal of Accounting, Vol. 14 No. 1, pp. 105-20.

Bruce, S.W. (1988), Certified Public Accountants: A Profession in Crisis, unpublished PhD Thesis, Claremont Graduate School.

Burchell, S., Clubb, C. and Hopwood, A.G. (1985), "Accounting in its Social Context: Towards a History of Value Added in the United Kingdom", Accounting, Organizations and Society, Vol. 10 No. 4, pp. 381-413.

Burchell, S., Clubb, C., Hopwood, A.G., Hughes, J. and Nahapiet, J. (1980), "The Roles of Accounting in Organizations and Society", Accounting, Organizations and Society, Vol. 5 No. 1, pp. 5-27.

Carnegie, G.D. and Napier, C.J., (1996), "Critical and Interpretive Histories: Insights into Accounting's Present and Future Through Its Past", Accounting, Auditing and Accountability Journal, Vol. 9 No. 3, pp. 7-39.

Central Bank (1987), The Role of External Auditors in the Supervision of Financial Institutions in Malaysia, SEACEN, Kuala Lumpur.

Chan, P. and Horii, K. (1986), Impact of the New Economic Policy on the Malaysian Economy: With Special Reference to Ownership and Control, Institute of Developing Economies, Tokyo. 
Chandra, M. (1989), Challenges and Choices in Malaysian Politics and Society, Aliran, Penang.

Chee, S.H. (1971), Sociocultural Pluralism and Political Change: The Dilemmas of the Bimodal Society in Malaya, unpublished PhD Thesis, University of Pittsburgh.

Choo, K.E. (1991), 'Trust Me' Approach of Professional Accountants vs 'Show Me' Attitude of the Public Towards Professional Ethics, paper presented at the MIA and MACPA jointly organised 7th National Accountants Conference, 18-19 September, Kuala Lumpur

Committee on International Accounting Operation and Education, 1976-78, of the American Accounting Association (1978), Accounting Education and the Third World, American Accounting Association, Altamonte Springs, Florida.

Cooper, D. and Sherer, M.J. (1984), "The Value of Corporate Accounting Reports: Arguments for a Political Economy of Accounting", Accounting, Organizations and Society, Vol. 9 No. 3/4, pp. 207-32.

Dahl, R.A. (1967), Pluralist Economy in the United States, Rand McNally.

Djojohadikusomo, S. (1968/69), Trade and Aid in South-East Asia, Vol. 1: Malaysia and Singapore, University of Malaya Co-op, Kuala Lumpur.

Dyball, M.C. and Valcarcel, L.J. (1999), "The "Rational" and "Traditional": The Regulation of Accounting in the Philippines", Accounting, Auditing \& Accountability Journal, Vol. 12 No. 3, pp. 303-27.

Dye, T.R. (1986), Who's Running America? 4th ed., Prentice-Hall.

Edwards, C.B. (1975), Protection, Profits and Policy: An Analysis of Industrialisation in Malaysia, unpublished $\mathrm{PhD}$ Thesis, University of East Anglia.

Enthoven, A.J.H. (1973), Accountancy and Economic Development Policy, North-Holland Publishing Company, Amsterdam.

Enthoven, A.J.H. (1977), Accountancy Systems in Third World Economies, North-Holland Publishing Company, Amsterdam.

Flint, D. (1983), “The Scope for Auditing Research", in Discussion Papers of Symposium on Auditing Research, The University of Glasgow Press, pp. 1-17.

Friedland, J. (1989), “A Call to Account”, Far Eastern Economic Review, 9 November, pp. 70-5.

Gale, B. (1985), Politics and Business: A Study of Multi-Purpose Holdings Berhad, Eastern Universities Press, Petaling Jaya.

Gomez, E.T. (1990), Politics in Business: UMNO's Corporate Investments, Forum Enterprise, Petaling Jaya.

Gomez, E.T. (1994), Political Business: Corporate Involvement of Malaysian Political Parties, Centre for South-East Asian Studies, James Cook University, Townsville, Queensland.

Gomez, E.T. (1997), "The Economics and Politics of Privatization in Malaysia", Journal of the Asia Pacific Economy, Vol. 2 No. 2, pp. 178-200.

Gul, F. (1983), History and Development of Accounting Education in Malaysia, The Regional Institute of Higher Education and Development, Singapore.

Hagiwara, Y. (1972), "Political Culture and Communalism in West Malaysia", The Developing Economies, Vol. 10 No. 3, pp. 250-66. 
Hai, G.J. (1970/71), "Recent Legislation on the Profession of Accountancy in Malaysia and Singapore", The Accounting Journal, Vol. 1 No. 1, pp. 25-36.

Hanafiah, N. (1990), Ethical Standards in the Accounting Profession, paper presented at the Universiti Utara Malaysia and Petronas jointly organised Seminar on Management Ethics, 13-14 March, Kuala Lumpur.

Hara, F. (1991), "Malaysia's New Economic Policy and The Chinese Business Community", The Developing Economies, Vol. 29 No. 4 , pp. 350-70.

Hirschman, C. (1983), "Ownership and Control in the Manufacturing Sector of West Malaysia", in Lim, D. (Ed.) Further Readings on Malaysian Economic Development, Oxford University Press, Kuala Lumpur, pp. 209-220.

Hirschman, C. (1971), "Ownership and Control in the Manufacturing Sector of West Malaysia", UMBC Economic Review, Vol. 7 No. 1, pp. 20-39.

Hopper, T. and Powell, A. (1985), "Making Sense of Research into the Organizational and Social Aspects of Management Accounting: A Review of its Underlying Assumptions [1]", Journal of Management Studies, Vol. 22 No. 5, pp. 429-65.

Hopper, T.M., Storey, J. and Willmott, H. (1987), “Accounting for Accounting Towards the Development of a Dialectical View", Accounting, Organizations and Society, Vol. 12 No. 5, pp. 437-56.

Hopwood, A.G. (1987), "The Archeology of Accounting Systems", Accounting, Organizations and Society, Vol. 12 No. 3, pp. 207-34.

Horii, K. (1991), "Disintegration of the Colonial Economic Legacies and Social Restructuring in Malaysia", The Developing Economies, Vol. 24 No. 4, pp. 281-313.

Hui, L.M. (1983), "The Ownership and Control of Large Corporations in Malaysia: The Role of Chinese Businessmen" in Lim, L.Y.C. and Gosling, L.A.P. (Eds), The Chinese in Southeast Asia: Ethnicity and Economic Activity, Vol. I, Maruzen Asia, Singapore, pp. 275-315.

Hui, L.M. (1988), "Contradictions in the Development of Malay Capital: State, Accumulation and Legitimation", in Taylor, J.G. and Turton, A. (Eds), Sociology of 'Developing Societies' Southeast Asia, Macmillan Education Ltd., London, pp. 19-32.

Humphrey, C., Moizer, P. and Turley, S. (1992), "The Audit Expectations Gap - Plus Ca Change, Plus C'est La Meme Chose?", Critical Perspectives on Accounting, Vol. 3 No. 2, pp. 137-61.

Ismail, M. S. (1994), "The Role of Public Sector in the Malaysian Economy", in National Institute of Public Administration Malaysia (Ed.), Malaysian Development Experience: Changes and Challenges, INTAN, Kuala Lumpur.

Jacob, R. (1992), “Can You Trust That Audit?”, Fortune, 18 November, pp. 91-4.

Jesudason, J.V. (1989), Ethnicity and the Economy: The State, Chinese Business, and Multinationals in Malaysia, Oxford University Press, Singapore.

Johnson, T.J. and Caygill, M. (1971), "The Development of Accounting Links in the Commonwealth", Accounting and Business Research, Vol. 1 No. 2, pp. 155-73.

Jomo, K.S. (Ed.) (1995), Privatizing Malaysia: Rents, Rhetoric, Realities, Westview Press, Oxford.

Jomo, K.S. (1986), A Question of Class: Capital, the State, and Uneven Development in Malaya, Oxford University Press, Singapore. 
Junid, S. (1980), British Industrial Investments in Malaysia, 1963-1971, Kuala Lumpur: Oxford University Press.

Kennedy, J. (1993), A History of Malaya, 3rd ed., S. Abdul Majeed and Co., Kuala Lumpur.

Koon, T.Y. (1994), Employee Fraud in Malaysia: A Case Study, unpublished PhD Thesis, University of London.

Kuala Lumpur Stock Exchange and Malaysian Strategic Consultancy Sdn. Bhd. (Eds.) (1992), Malaysia The Rising Star: Business and Investment Opportunities and Challenges Towards 2020, KLSE and MSC Sdn. Bhd., Kuala Lumpur.

Kunio, Y. (1988), The Rise of Ersatz Capitalism in South-East Asia, Oxford University Press, Singapore.

Lehman, C. and Tinker, A. (1987), "The 'Real' Cultural Significance of Accounts", Accounting, Organizations and Society, Vol. 12 No. 5, pp. 503-22.

Leigh, M. (1992), "Politics, Bureaucracy, and Business in Malaysia: Realigning the Eternal Triangle", in MacIntyre, A.J. and Jayasuriya, K. (Eds.), The Dynamics of Economic Policy Reform in South-East Asia and the South-West Pacific, Oxford University Press, Singapore, pp. 115-23.

Leong, H.K. (1988), Indegenizing the State: The New Economic Policy and the Bumiputera State in Peninsular Malaysia, unpublished Phd Thesis, Ohio State University.

Liang, F.S. (1989), "How Old is the Auditing Profession in Singapore?" Singapore Accountant, Vol. 5 No. 7, pp. 9-10.

Lim, D. (1973), Economic Growth and Development in West Malaysia, Oxford University Press, Kuala Lumpur.

Limlingan, V.S. (1986), The Overseas Chinese in ASEAN: Business Strategies and Management Practices, Vita Development Corporation, Manila.

Limlingan, V.S. (1994), The Visible Hand and the Developing Economy: Essays on Management in Southeast Asia, 2nd ed., De La Salle University Press, Manila.

Linderberg, M.M. (1973), Foreign and Domestic Investment in the Pioneer Industry Program, Malaysia 1965-1970, Political, Economic, and Social Impacts, unpublished PhD Thesis, University of Southern California.

Loft, A. (1986), "Towards a Critical Understanding of Accounting: The Case of Cost Accounting in the U.K., 1914-1925", Accounting, Organizations and Society, Vol. 11 No. 2, pp. 137-69.

Means, G.P. (1986), "Ethnic Preference Policies in Malaysia", in Nevitte, N. and Kennedy, C.H. (Eds), Ethnic Preference and Public Policy in Developing Societies, Lynne Reinner Publishers, Inc., Boulder, Colorado, pp. 95-118.

Megat, A.R. (1979), Future of the Accountancy Profession in Malaysia, paper presented at the MACPA 21st Anniversary Seminar, 29 September, Kuala Lumpur.

Miller, P. and O'Leary, T. (1987), "Accounting and the Construction of the Governable Person”, Accounting, Organizations and Society, Vol. 12 No. 3, pp. 235-65.

Mohd.-Ariff, Y. (1993), Securities Commission: Regulator of the Capital Market, paper presented at the 9th National Accountants' Conference, 20-21 July, Kuala Lumpur.

Mohd.-Salleh, M. (1989), The Equity Structure of Listed Companies, paper presented at the Persatuan Sains Sosial Malaysia and Institut Pengajian Tinggi, Universiti Malaya jointly 
organised New Economic Policy and Its Future conference, 24-26 July, Universiti Malaya.

Mohd.-Salleh, M. (1993), "The Malaysian Capital Market: New Rules of the Game”, Capital Markets Review, Vol. 1 No. 1, pp. 1-21.

Mohd.-Sheriff, M.-K. (1992), "Economic Outlook and Privatization Trends Towards 2020" in Kuala Lumpur Stock Exchange and Malaysian Strategic Consultancy Sdn. Bhd. (Eds), Malaysia The Rising Star: Business and Investment Opportunities and Challenges Towards 2020, KLSE and MSC Sdn. Bhd., Kuala Lumpur, pp. 215-24.

National Operations Council (1969), The May 13 Tragedy: A Report, National Operation Council, Kuala Lumpur.

Needles, B.E., Jr. (1976), "Implementing a Framework for the International Transfer of Accounting Technology", International Journal of Accounting, Vol. 12 No. 1, pp. 45-62.

Ong, B.K. (1987), "Market Manipulation and the Securities Industry Act 1983", The Malaysian Accountant, Vol. 2 No. 4, pp. 25-31.

Onn, F.C. (1989), Malaysian Corporate Economy Restructuring: Progress Since 1970, paper presented at the Persatuan Sains Sosial Malaysia and Institut Pengajian Tinggi, Universiti Malaya jointly organised New Economic Policy and Its Future conference , 24-26 July, Universiti Malaya.

Parker, W.C., Jr. (1973), Communications and the May 13th Crisis: A Psychocultural Interpretation, University Malaya Press, Kuala Lumpur.

Peng, K.K. (1979), Dependence and the Malaysian Economy, unpublished Master Thesis, Universiti Sains Malaysia.

Peng, K.K. (1983), The Malaysian Economy, Marian and Sons (Mal.) Sdn. Bhd., Kuala Lumpur.

Peng, O.C. (1989), Auditor's Report - Where Lies its Values?, paper presented at the MIA and MACPA jointly organised 5th National Accountants Conference, 31 July-1 August, Kuala Lumpur.

Phenix, P. (1986), Directors, Shareholders and Auditors Under the Companies Act 1965 - As Amended, The Malaysian Accountant, April, pp. 7-16.

Pillai, P.N. (1984), Companies and Securities Handbook - Singapore \& Malaysia, Butterworths, Singapore.

Puthucheary, J. (1960), Ownership and Control in the Malayan Economy, Eastern Universities Press Ltd., Singapore.

Ram, G.S. (1985), Criminal Law and Commercial Crimes, paper presented at the HRM Fighting Financial Fraud, 21-22 January, Kuala Lumpur.

Redha, A. (1985), "Capital Accumulation and the State in Malaysia", Ilmu Masyarakat, No. 8, January-March, pp. 1-27.

Report on the 3rd ASEAN Federation Accountants Conference, 8-11 September, 1982, Bangkok.

Rohwer, J. (1995), Asia Rising: How History's Biggest Middle Class Will Change the World, Butterworth-Heinemann Asia, Singapore.

Sakagami, M., Yoshimi, H. and Okano, H. (1999), "Japanese Accounting Profession in Transition”, Accounting, Auditing \& Accountability Journal, Vol. 12 No. 3, pp. 340-57. 
Samuels, J.M. and Piper, A.G. (1985), International Accounting: A Survey, Croom Helm, London.

Saruwatari, K. (1991), "Malaysia's Localization Policy and its Impact on British-Owned Enterprises", The Developing Economies, Vol. 24 No. 4, pp. 371-386.

Schlossstein, S. (1991), Asia's New Little Dragons: The Dynamic Emergence of Indonesia, Thailand and Malaysia, Contemporary Books, Chicago.

Seidler, L.J. (1967), The Function of Accounting in Economic Development - Turkey as a Case Study, Frederick and Prager Publishers, London.

Shing, G.Y.Y. (1981), “The Audit License”, The Malaysian Accountant, Vol. 2 No. 2, pp. $32-3$.

Siang, L.K. (1982), Malaysia in the Dangerous 80s, Democratic Action Party, Petaling Jaya.

Siang, L.K. (1986), Malaysia: The Crisis of Identity, Democratic Action Party, Petaling Jaya.

Sikka, P., Willmott, H.C. and Lowe, T. (1989), "Guardians of Knowledge and Public Interest: Evidence and Issues of Accountability in the UK Accountancy Profession", Accounting, Auditing and Accountability Journal, Vol. 2 No. 2, pp. 47-71.

Sum, H.L.C. and Wishart, D.A. (1989), "Commercial Law”, in Krishnan, A. (Ed.), Survey of Malaysian Law, Malayan Law Journal Sdn. Bhd., Kuala Lumpur, pp. 113-24.

Susela, S.D. (1999), “'Interests' and Accounting Standard Setting in Malaysia”, Accounting, Auditing and Accountability Journal, Vol. 12 No. 3, pp. 357-87.

Syed, H.A. (1984), "Social Relations: The Ethnic and Class Factors", in Syed, H.A. (Ed.), Ethnicity, Class and Development in Malaysia, Malaysian Science Social Association, Kuala Lumpur, pp. 13-31.

Tay, J.S.W. (1994), "Malaysia", in Cooke, T.E. and Parker, R.H. (Eds.), Financial Reporting in the West Pacific Rim, Routledge, London, pp. 231-64.

Teik, G.C. (1971), The May Thirteenth Incident and Democracy in Malaysia, Oxford University Press, Kuala Lumpur.

Tinker, A.M. (1980), “Towards a Political Economy of Accounting: An Empirical Illustration of the Cambridge Controversies", Accounting, Organizations and Society, Vol. 5 No. 1, pp. $147-60$.

Tong, T.L. and Ann, C.T. (1996), "Non-Disclosure in the Abridged Profit and Loss Accounts of Malaysian Listed Corporations", The Malaysian Accountant, April, pp. 2-5.

Tong, T.L., Zainal, A.K. and Wah, C.P., (1989), Information Needs of Users and Voluntary Disclosure Practices of Malaysian Listed Corporations, paper presented at the International Accounting Seminar on Accounting Trends, Issues and Challenges, 22-24 August, Universiti Pertanian Malaysia.

Vreeland, N., Dana. G.B., Hurwitz, G.B., Just, P., Moeller, P.V. and Shinn, R.S. (1976), Area Handbook for Malaysia, 3rd. ed., U.S. Government Printing Office, Washington, D.C.

Wai, T.T. (1982), Income Distribution and Determination in West Malaysia, Oxford University Press, Kuala Lumpur.

Walton, P. (1986), "The Export of British Accounting Legislation to Commonwealth Countries", Accounting and Business Research, Vol. 16 No. 64, pp. 353-57. 
Willmott, H.C. (1985), "Setting Accounting Standards in the UK: The Emergence of Private Accounting Bodies and Their Role in the Regulation of Public Accounting Practice", in Streeck, W. and Schmitter, P. (Eds.), Private Interest Government: Beyond Market and State, Sage, London.

Willmott, H.C. (1991), "The Auditing Game: A Question of Ownership and Control”, Critical Perspectives on Accounting, Vol. 2 No. 1, pp. 109-21.

Woon, T.K. and Kam, W.P. (1989), Restructuring of Employment, paper presented at the Persatuan Sains Sosial Malaysia organised National Economic Policy and Its Future seminar, 24-26 July, Kuala Lumpur.

Woon, T.K. (1982), "The Role of the Malaysian State in the Restructuring of Employment", Jurnal Ekonomi Malaysia, No. 6, December, pp. 32-62.

Yan, L.S. (1994), “The Malaysian Economy, 1957-91: An Overview”, in National Institute of Public Administration Malaysia (Ed.), Malaysian Development Experience: Changes and Challenges, INTAN, Kuala Lumpur, pp. 553-90.

Yun, H.A. (1984), "Capitalist Development, Class and Race”, in Syed H.A. (Ed.), Ethnicity, Class and Development in Malaysia, Malaysian Science Social Association, Kuala Lumpur, pp. 296-328.

Zainal-Aznam, Y. (1991), "Distributional Policies and Programmes: The Malaysian Experience", in Hock, L.K. and Nagaraj, S. (Eds.), The Malaysian Economy Beyond 1990: International and Domestic Perspectives, Persatuan Ekonomi Malaysia, Kuala Lumpur, pp. 343-79.

Zainal-Aznam, Y. (1994), "Growth and Equity in Malaysia", in National Institute of Public Administration Malaysia (Ed.), Malaysian Development Experience: Changes and Challenges, INTAN, Kuala Lumpur, pp. 591-616.

\section{Annual Reports}

Central Bank Annual Report: 1963.

MACPA Annual Reports: 1976, 1977, 1981, 1982, 1984.

MIA Report and Accounts: 1967-1987, 1988, 1989, 1990, 1991, 1992, 1993, 1994, 1995, 1996.

\section{Official Documents}

The First Outline Perspective Plan, 1970-1990.

The Malaysian Plans: From the First (1966-1970) to the Seventh (1996-2000).

The Mid-Term Reviews of the Malaysian Plans: From the First (1966-1970) to the Sixth (1991-1995).

The Second Outline Perspective Plan, 1991-2000.

Parliamentary Debates (Vol. II, no. 8, Col. 1558 and dated 9 Aug. 1965)

Parliamentary Debates (Vol. IV, No. 12, Col. 2409 and dated 25 Aug. 1967)

White Paper on the final report of the Committee of Inquiry into the BMF case, Command Paper 16, 1986.

White Paper on the position of Bank Rakyat, Command Paper 15, 1979. 


\section{Macrothink}

\section{Legislations}

Act No. 125, Companies Act and Companies Regulation (All Amendments up to March 1995), 15th ed., Kuala Lumpur: MDC Publishers Printers Sdn. Bhd.

Act No. 94, Accountants Act, 1967 and Accountant Rules 1972 (As at 14th July 1984), Kuala Lumpur: Malaysian Law Publishers Sdn. Bhd.

Act No. 94, Accountants Act, 1967 and Rules, 1972 \& Audit Act, 1967 (Act 62) (As at 10th February 1993), Kuala Lumpur: International Law Book Services.

\section{Professional and Popular Journals and Newspapers}

Akauntan Nasional

Berita Harian

Business Times

CERPASS

Far Eastern Economic Review

International Accounting Bulletin

Malaysian Business

Mingguan Malaysia

New Straits Times

New Sunday Times

The Malaysian Accountant

The Star

Utusan Malaysia

\footnotetext{
${ }^{\mathrm{i}}$ See remarks made by the then chairman of the Securities Commission (SC) (The Malaysian Accountant, Oct/Dec 1993, p. 15), the finance minister (Akauntan Nasional, Sept. 1989, pp. 21-23; Aug. 1990, p. 26; Oct. 1990, pp. 20-21) and those by Tun Ismail Ali, the former Governor of Central Bank and the chairman of the Bumiputra trust agency, Permodalan Nasional Berhad (PNB), and several listed companies (The Malaysian Accountant, July-Sept 1988, p. 18).

ii Just before the Companies Act 1965 was enforced, in 1965, the audit firm Peat, Marwick, Mitchell \& Co. located in Kuala Lumpur was sued by plaintiffs who were shareholders of a company - Kiwi Dry Cleaners Ltd. - at the High Court of Malaya (Civil Suit No. 324 of 1965 Kuala Lumpur). See (1967) 1 MLJ 87. (MLJ stands for Malayan Law Journal.)

${ }^{\text {iii }}$ From hereon it is referred to as NST.

${ }^{\text {iv }}$ For example, as noted Malaysian Medical Council chairman Professor Datuk Dr Mahmood Mohd Noor, "[t]he number of medical negligence or malpractice suits in Malaysia is relatively few but the cases filed over the last two years were more than the average for the previous five years" (NST, 29 Dec. 1994). As a result, it is reported that the Law Ministry is now looking into ways to introduce limits on the amount of money a plaintiff can claim (NST, 29 Dec. 1993).

${ }^{v}$ This view of his was however different to that of the former, for Oh Chong Peng (1989) did say that some amount of pressure for change had been dispensed by regulatory authorities like the Capital Issues Committee
} 
(which was replaced by the Securities Commission in 1992) and the Central Bank.

${ }^{\mathrm{vi}}$ Deloitte Touche Tohmatsu was criticised by a Hong Kong inspector over audits it conducted for a group of companies which were under criminal investigation (International Accounting Bulletin, 8 Nov 1993, p. 1). The firm was alleged to have committed audit failure leading to the publication of misleading financial statements. In Singapore, the collapse of Pan-El, a property, salvage and hotel group, resulted in an unprecedented three-day closure of the Kuala Lumpur and Singapore stock exchanges in December 1985, the demise of six broking firms and the trial of three key figures in the Pan-El Group on charges ranging from criminal breach of trust to share forgery (NST, 6 June 1988). The uproar over the alleged failure of the auditors to conduct proper audit was brought to public attention in late 1986 when the Singapore minister of finance mentioned in his speech in Parliament that there was "an inexplicable audit failure" in the Pan-El affair. The following year, the investigation undertaken by the Singapore Society of Accountants (SSA) culminated with Coopers \& Lybrand publicly faulted for the quality of its audit work. As for South Korea, in 1993, the country's Securities Supervisory Board (SSB), which regulates the nation's audit practice, issued warnings to seven of South Korea's audit firms for their alleged audit negligence (International Accounting Bulletin, 17 Jan. 1994, p. 4). This warning took place after SSB conducted a quality review of auditing practice of selected firms. Out of the seven firms warned, four were affiliates of the Big Six (now Big Four). Finally, in the case of India, as a result of the loss of US\$1.5 billion through a securities fraud involving banks and mutual funds, the auditors were criticised by a Joint Parliamentary Committee (JPC) set up by the Parliament to investigate the case (International Accounting Bulletin, 14 March 1994, p. 3). Not surprisingly, the Reserve Bank of India (RBI) in 1993 dropped from its list of auditors for 1992/3 about 20 audit firms which acted as auditors for the institutions involved during the 1991/2 fiscal year (International Accounting Bulletin, 21 June 1993, p. 2). These firms which included all the Big Six were ordered to take a one year "period of rest".

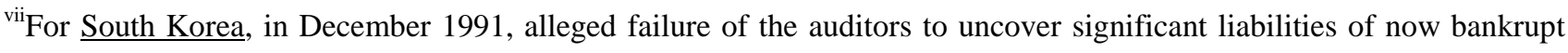
companies had led to the investors filing the first ever lawsuit against the auditors (International Accounting Bulletin, Feb. 1992, p. 3). As for Singapore, in 1988, the former shareholders of Pan-El sued its group auditor, Coopers \& Lybrand, for US\$105 million (NST, 6 June 1988). It perhaps needs to be noted too that early on in December 1987, a former partner of another accounting firm, acting as auditor for a number of Pan-El's subsidiaries, pleaded guilty to a criminal charge brought against him for issuing a misleading audit report. He was sentenced to two months in jail and fined for $\mathrm{S} \$ 10,000$.

viii Note that Dahl (1967) defines power and conflict as the ability to impose one's will upon another and the existence of more than one interest, respectively.

${ }^{\text {ix }}$ Dye (1986) argues that a cohesive "power elite" exercise authority over a variety of institutions. This elite is comprised of a small group of dominant, authoritative individuals or entities. The elite functions through, among other things, interlocking directorships, interlocking institutional experiences and similar social backgrounds. However, instead of a single power elite, Dye says that a society may have different groups of individuals or entities which exercise power in its various sectors. Thus, leadership or authority is dispersed. More importantly perhaps it is not unusual for these elites to be in conflict with each other.

${ }^{\mathrm{x}}$ Examples of link-ups include Jaffar Hussein with Price Waterhouse, Kassim Chan \& Co with Deloitte, Haskins and Sells, Desa Megat \& Co with KPMG Peat Marwick, A. Samad \& Co, Hanafiah Raslan \& Mohamad with Arthur Andersen, Lim Ali \& Co and Larry Seow and Co with Arthur Young International, Mustapha Law with Touche Ross International and Nordin Hanifah \& Co with Ernst \& Whinney. For 15 years up to 1988, Hanafiah Raslan \& Mohamad (HRM) was linked with Touche Ross International. Following the merger overseas between DHS and Touche Ross (and Tohmatsu Awoki \& Sanwa), their local counterparts - Kassim Chan and Mustapha Law respectively - also merged. The same also took place with their local counterparts when Ernst and 
Whinney merged with Arthur Young in July 1990.

${ }^{x i}$ Previously in the Federation of Malaya, company law was governed by the Companies Ordinance 1946, whilst in the State of Singapore, it was governed by the Straits Settlements Ordinance 1940. The Sarawak Companies Ordinance was similar to the North Borneo Companies Ordinance, which was based on Hong Kong companies legislation which in turn was modelled from the English Companies Act of 1929.

${ }^{x i i}$ Note however that in the Parliamentary Debates (Vol. II, no. 8, Col. 1558 and dated 9 Aug. 1965), it was stated by the then minister of commerce and industry, Dr. Lim Swee Aun, that the committee with the responsibility to draft the Companies Bill (whose chairman came from the ministry of commerce and industry and with the assistance of John Finemore, a Colombo Plan draftsman from Australia) had considered not only the present legislation in force in the UK, Australia, India and New Zealand but also the draft code prepared for Ghana by Professor Gower and the reports presented in the UK by the committees chaired by Lord Cohen and Lord Jenkin.

xiii The MIA president mentioned in 1987 that the power to issue audit and liquidator licenses had been delegated in accordance with Section 8(7) of the Companies Act 1965, to a committee in the finance ministry (The Malaysian Accountant, Oct-Dec 1987, p. 10). He did not say however when this committee had actually started its operation.

${ }^{x i v}$ The public and registered members are those with accounting bachelor or post-graduate diploma degrees from local higher institutions or accounting professional qualifications from MIA's recognised local and overseas accounting bodies. To become a member, he or she also needed to have three to five years relevant experience in public accounting firms for public accountants and in commerce/industry/public sector entity for registered accountants. (Five years are the rule. But it will be shortened to four years for those with High School Certificate and to three years for those graduating with degrees or diploma from local higher institutions.) The recognised accounting bodies (as listed in the Accountants Act's First Schedule) are the Chartered Institutes of Scotland, England and Wales, Ireland, Australia, Canada and India; the Societies of Accountants of Australia and New Zealand; the Association of Certified Accountants (UK); the Institute of Cost and Management Accountants (UK); and Malaysian Association of Certified Public Accountants (MACPA). As for the licensed accountants, they do not have MIA recognised accounting qualifications but are allowed to practice for either one of the following two reasons: they are already in operation as accountants, tax-consultants or tax advisers prior to the passing of the Accountants Act in 1967; the finance minister has granted them limited approval to act as company auditor under Section 8(6) of the Companies Act 1965.

${ }^{\mathrm{xv}}$ The Act however with regard to a tax consultant or a tax adviser has a provision allowing him or her to practice or hold him/herself out as one when he or she has the authority to do so as granted by any other law that is enforced within the country.

${ }^{x v i}$ R.D. Stewart (1958/59), W.M. Piercy (1959 to 1961) and H.R. Villiers (1961/62) (MACPA 1977 Annual Report, p. 3) who came from the audit firms Turquand, Youngs \& Co., Evatt \& Co. and Peat, Marwick, Mitchell \& Co., respectively.

${ }^{x v i i}$ Some sort of assistance by the ICAEW appears to have also taken place in the early 1980s. See the MACPA 1981 (p. 17) and the 1982 (p. 17) Annual Reports.

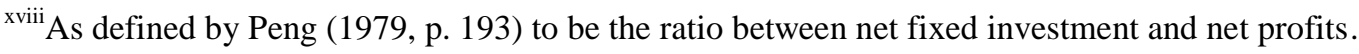

${ }^{x i x}$ The unofficial estimate of the total dead however was as high as six or seven hundreds. The riots took place in the aftermath of the May 1969 general election when the Chinese-dominated opposition parties registered impressive gains at the polls. They celebrated their victory by taunting the Malays on Malay areas of Kuala Lumpur. The Malays in turn organised counterdemonstrations which moved into Chinese quarters. With insults exchanged on the streets, rioting ensued (see Bass, 1973; Parker, 1973; Chee, 1971; Teik, 1971; and National Operations Council, 1969). Though the immediate cause of the riots appeared clear, there is a general concurrence that the riots had a long historical roots planted by the British whose various conducts during the colonial time had led to the fact that after independence the rich and poor were also separated by ethnic origins with the former viewed as immigrants while the latter, indigenous to the 
region. For excellent discussion of the relationship between race and class in Malaysia, see Brennan (1985), Yun (1984), Syed (1984) and Hagiwara (1972). Also, in the few years preceding the racial riots, unemployment was increasing and problem of peasant landlessness among the Malays continuing (Jomo, 1986, p. 252). Malay discontent was compounded by Chinese (and Indian) resentment over what they saw as the government advancing the interests of Malays over other races - e.g. by provision of "special privileges" and ethnic employment quotas (Jomo, 1986, p. 252). Therefore, for both Malays and non-Malays, their dissatisfactions were focused on issues that were basically ethnic in character.

${ }^{\mathrm{xx}}$ The excessive speculation in the then Malayan Stock Exchange formed in 1960 was duly noted in the Central Bank 1963 Annual Report. And when the Securities Industry Act 1973 (SIA) was finally enforced in 1976 to provide the government with powers to curb various forms of market manipulation, it did not result in anything new in the way the market was treated by investors and even their own regulators. As noted Ong (1987, p. 26): "The Malaysian experience has so far been one of wide and sudden fluctuations in prices. Allegations of market-rigging and manipulation and other forms of securities frauds, failure by the KLSE both to maintain an orderly market and to instil confidence in both the investors and the government that it is an effective regulatory body, and a situation where members of the regulatory body, that is, the KLSE's committee, have themselves been disciplined by the Registrar instead of their disciplining errant members."

${ }^{\mathrm{xx}} \mathrm{He}$ was among the first few Bumiputra sent to Australia under the Colombo Plan to do accounting (Business Times, 17 Aug. 1989). He qualified as chartered accountant in 1960 after five years with Price Waterhouse in Melbourne. Upon his retirement in 1989, he took over the business of the audit firm Baharom-Jasani (Business Times, 17 Aug. 1989). In 1991, it was reported (The Star, 10 July 1991) that Shamsir Jasani \& Co, the seventh largest accounting firm in the country, had 130 staff and was backed by Grant Thornton International.

${ }^{x x i i}$ From both the documented sources and interviews, a variety of answers is found as to why the MIA limited itself to play a "registering role" for two decades (see Azham, 2002).

${ }^{x x i i i}$ MACPA appeared to say however that the merger discussion only began sometime during 1976 (see the MACPA 1976 Annual Report, p. 8).

${ }^{x x i v}$ Note that this remark was probably made in response to the criticism made by the then Central Bank's Governor, Tan Sri Jaafar Hussein, towards the MACPA leadership (see The Malaysian Accountant, July 1986, p. 6). Note also that an interviewee who had been involved with the MACPA investigation committee for several years mentioned that the MACPA could be more strict in punishing errant members.

${ }^{\mathrm{xx}}$ That of the equity requirements on investment in most business enterprises: 30 percent equity in a business enterprise for Bumiputra, 40 percent for other Malaysians and 30 percent foreigners.

${ }^{x x v i}$ In terms of the number of companies listed, the increase was from 321 listed in 1992 to over 500 companies by the end of 1995. At the end of 1993, the market value of the KLSE had also jumped to RM 620 billion - an increase of 152 percent from the RM 246 billion recorded at the end of the previous year (NST, 14 May 1994). In 1993 too, the total volume and turnover rose to 108 billion units valued at RM 387 billion, which exceeded the combined volume and turnover for the past 20 years! In 1994, the International Finance Corporation, an affiliate of the World Bank, posted in the Internet that the KLSE's market capitalisation as at November 1993 was US\$175 billions - the second biggest after Hong Kong among 22 emerging markets capitalisation. It is perhaps important to note that paralleling these numerical advances, the government during the same period had embarked on a number of steps related to the nation's securities market - a continuation of those taken in the last half of 1980s. These included requiring the formation of audit committee for listed companies (Akauntan Nasional, Nov/Dec. 1993, p. 26), the setting up Securities Commission (SC) (Yusof, 1993; Mohd.-Salleh, 1993), both in 1993, and the upgrading of penalties for any breach of the KLSE listing requirements from public reprimands and suspension of trading to fines of up to RM 100,000 (NST, 30 Sept. 1994) in the following year. 
Finally, in 1995, the government unveiled an 18-point liberalising package for the capital market with local and international objectives.

${ }^{\text {xxvii }}$ The merger proposal was rejected on 17 June, 1985. Reason given was that there was no need for the merged body the MICA for there was already in the country an accounting body entrusted with all the needed task to spearhead the accounting profession in the form of the MIA (MIA Annual Report, 1967-87, p. 11). The interviews had however found that there was no "outright" rejection by the government. See Azham (2002).

xxviii In other words, the MIA was supposed to be a full-fledged accounting professional body. But later next year, in the Parliament, at a time when the media was having a field day reporting on the public quarrels between the leaders of the MIA and the MACPA (see Azham, 2002), his deputy made remarks which were not encouraging at all to those in the MIA. He said that the MIA should continue to oversee the MACPA and other professional accounting bodies (The Star, 12 Oct. 1988; Business Times, 12 Oct. 1988). Both bodies he claimed had different functions and responsibilities. He also said that through the Accountants Act 1967, the MIA was set up to monitor, regulate and coordinate the accounting profession for the purpose of safeguarding public interest and ensuring high professional standards. The MIA in short was to act as mere supervisory and coordinating body for the rest of accounting professional bodies in the country.

${ }^{x x i x}$ The apparent exceptions took place in two cases: one in 1992 when the MIA president was reported to say that the MIA had found from its recent investigation involving 40 accountants that there were auditors who had failed to issue proper audit report (NST, 12 Apr. 1992). And another in 1993 under the headline "MIA Warning to Errant Members" (NST, 28 Jan. 1993). But on closer inspection, the story involved members of MIA who colluded with unqualified accountants. Thus, this story was nothing new. It is because on this very subject of collusion between members and the so-called unqualified accountants, the MIA over the years was fond of issuing numerous statements to the media making one warning after another that stern action would be taken against its members with really no news whether in fact actions had been taken. See The Malay Mail (4 Feb. 1988; 26 Feb. 1992) and NST (17 Sept. 1988; 31 Jan. 1991).

${ }^{\mathrm{xxx}}$ The MIA in contrast to that of the MACPA did not divulge the types of disciplinary action taken against the members in its annual reports. Why it did not find fit to clearly spell what these actions were appears to be one of those questions whose answers are everyone's guesses.

${ }^{x x x i}$ The excuse for no disciplinary actions taken in 1989 was this as appeared in the MIA 1989 Annual Report (p. 13): Dato' Shamsir Omar who was sitting in the disciplinary committee left the council and thus the committee too due to his retirement from his position as the then Accountant-General. As for the year 1990, the excuse as found in the MIA 1990 Annual Report (p. 13) was this: shortage of manpower "especially" with the resignation of the Institute's legal officer.

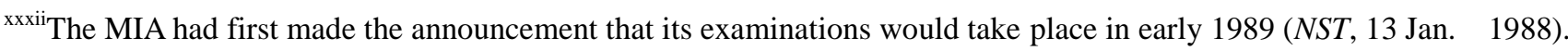
This was moved later on to the end of 1989 (NST, 20 Aug. 1988). Next it was reported that the exams would take place by the middle of 1990 (NST, 19 Dec. 1988) and in another report (NST, 18 March 1989) in August 1990. In 1992, the MIA president declared that the first sitting of the examinations would take place in December 1993 (Akauntan Nasional - Conference Times, 15 July 1992, p. 1). Finally, it was stated that the examinations would be set up in 1994 (NST, 28 Jan. 1993). At the end, it was in 1996, at a time when the nation seemed to have arrived at the peak of its economic development that the MIA had finally begun to offer the professional examination.

xxxiii Note that Chandra Muzaffar and Aliran appear to be well versed in this subject matter. Check for example Aliran (1981a, Chapter Three), Aliran (1981b), Aliran (1988a, Chapter Four) and Chandra (1989, pp. 47-56). For more on the same subject, please check also the following: The speeches made by Lim Kit Siang on 25 October 1977, 27 October 1975 and 14 July 1971 which appear in Siang (1978); the section entitled "On a Clean, Efficient and Democratic Government" in Siang (1986); and finally Schlossstein (1991, Chapter Four). 
${ }^{\text {xxxiv }}$ The number of companies had grown from about 4,000 in 1963 (Business Times, 24 Apr. 1997) to 66,105 companies in 1980 (NST, 13 Nov. 1992) and to 201,705 companies in 1990 (Business Times, 18 Sept. 1996). In 1993, there were 277,018 (Business Times, 18 Sept. 1996). Note also that the NST (23 Apr. 1997) reported that since 1994, the number of new companies registered yearly in the country was roughly 40,000. By the end of 1996, there were 418,893 companies (NST, 23 Apr. 1997).

${ }^{\mathrm{xxx}}$ Perhaps it was because at that time Malaysia was getting bogdown by the Asian Financial Crisis? So, there was no need for additional bad news that could only make the economy worse off? It perhaps needs to be noted that on the eve of the Asian Financial Crisis, just a few months after the operation had begun, the NST (8 July 1997) did file a report on remarks coming from the domestic trade and consumer affairs minister that there were five cases of auditors obstructing the ROC officers in conducting their inspection which to that date numbered to 123 audit firms. He also mentioned that the southern branch of the MIA had sent out circulars asking its members not to co-operate with the ROC should their firms be called for inspection. So, he reminded the auditors to co-operate with the ROC or face legal action. 